\title{
How to elucidate and control the redox sequence in vinylbenzoate and vinylpyridine bridged diruthenium complexes $\dagger$
}

\author{
Florian Pevny, ${ }^{a, b}$ Rainer F. Winter, ${ }^{* a, b}$ Biprajit Sarkar ${ }^{c}$ and Stanislav Záliš ${ }^{d}$
}

\begin{abstract}
Vinylbenzoate-bridged diruthenium complexes $(\mathrm{RHC}=\mathrm{CH})(\mathrm{CO})\left(\mathrm{P}^{i} \mathrm{Pr}_{3}\right)_{2} \mathrm{Ru}\left(\mu-4-\mathrm{OOCC}_{6} \mathrm{H}_{4}-\mathrm{CH}=\mathrm{CH}\right)$ $\mathrm{RuCl}(\mathrm{CO})\left(\mathrm{P}^{i} \mathrm{Pr}_{3}\right)_{2}\left(\mathrm{R}=\mathrm{Ph}, 3 \mathrm{a}\right.$ or $\left.\mathrm{CF}_{3}, 3 \mathrm{~b}\right)$ and vinylpyridine-bridged $\left(\eta^{6}\right.$-p-cymene $) \mathrm{Cl}_{2} \mathrm{Ru}\left(\mu-\mathrm{NC}_{5} \mathrm{H}_{4}-4\right.$ $\mathrm{CH}=\mathrm{CH}) \mathrm{RuCl}(\mathrm{CO})\left(\mathrm{P}^{i} \mathrm{Pr}_{3}\right)_{2}(3 \mathrm{c})$ have been prepared from their monoruthenium precursors and investigated with respect to the sequence of the individual redox steps and electron delocalization in their partially and fully oxidized states. Identification of the primary redox sites rests on the trends in redox potentials and the EPR, IR and Vis/NIR signatures of the oxidized radical cations and is correctly reproduced by quantum chemical investigations. Our results indicate that the trifluoropropenyl complex $\mathbf{3 b}$ has an inverse FMO level ordering (Ru1-bridge-Ru2 > terminal vinyl-Ru1 site) when compared to its styryl substituted counterpart 3 a such that the primary oxidation site in these systems can be tuned by the choice of the terminal alkenyl ligand. It is further shown that the vinylbenzoate bridge is inferior to the vinylpyridine one with regard to charge and spin delocalization at the radical cation level. According to quantum chemical calculations, the doubly oxidized forms of these complexes have triplet diradical ground states and feature two interconnected oxidized vinyl ruthenium subunits.
\end{abstract}

\section{Introduction}

Vinyl ruthenium or osmium complexes possess highly delocalized occupied frontier orbitals that are largely centred on the unsaturated hydrocarbyl ligand, low oxidation potentials and good stabilities of their oxidized forms that surpass those of all but the most powerful donor substituted olefins. ${ }^{1-4}$ As such, they constitute excellent components for $\pi$-conjugated metal-organic hole-transporting materials. In order to achieve high hole mobilities in at least one dimension, many per se conducting individual building blocks must be interconnected in a manner that preserves an efficient pathway for extended $\pi$-conjugation. This in turn requires that the vinyl unit anchoring to the one metal atom and the donor function connecting to the other one belong to the same $\pi$-conjugated bridging ligand. Previous studies from our group have shown that the initial polaron in partially oxidized vinylpyridine-bridged di- and tetraruthenium complexes $\left(\mathrm{PPh}_{3}\right)_{2}(\mathrm{CO})(\mathrm{PhCH}=\mathrm{CH}) \mathrm{ClRu}(\mu-$ $\left.\mathrm{NC}_{5} \mathrm{H}_{4} \mathrm{CH}=\mathrm{CH}\right) \mathrm{RuCl}(\mathrm{CO})\left(\mathrm{P}^{i} \mathrm{Pr}_{3}\right)_{2} \quad$ (3d, Chart 1) and $\left\{\left(\mathrm{P}^{i} \mathrm{Pr}_{3}\right)_{2}(\mathrm{CO}) \mathrm{ClRu}\left(\mu-4-\mathrm{CH}=\mathrm{CHC}_{5} \mathrm{H}_{4} \mathrm{~N}\right) \mathrm{RuCl}(\mathrm{CO})\left(\mathrm{PPh}_{3}\right)_{2}\right\}_{2}(\mu-$ $\mathrm{CH}=\mathrm{CH}-\mathrm{C}_{6} \mathrm{H}_{4}-\mathrm{CH}=\mathrm{CH}-1,3$ and -1,4) is trapped at the electron rich terminal styryl or central divinylphenylene bridged diruthenium site with only a little delocalization across the ruthenium-pyridine bonds. ${ }^{3}$

"Institut für Anorganische Chemie der Universität Regensburg, Universitätsstraße 31, D-93040, Regensburg, Germany

${ }^{\circ}$ Present address: Fachbereich Chemie der Universität Konstanz, Universitätsstraße 10, D-78457, Konstanz, Germany

'Institut für Anorganische Chemie der Universität Stuttgart, Pfaffenwaldring 55, D-70569, Stuttgart, Germany

${ }^{d} J$. Heyrovsky' Institute of Physical Chemistry v.v.i, Academy of Sciences of the Czech Republic, Dolejskova 4, Prague, Czech Republic

$\uparrow$ Electronic supplementary information (ESI) available: Computational and spectral data. See DOI: $10.1039 / \mathrm{c} 0 \mathrm{dt} 00164 \mathrm{c}$
We are now exploring the vinylbenzoate- and vinylpyridinebridged dinuclear complexes of Chart 1 with respect to 1) their ability to direct the primary oxidation to the ruthenium-bridgeruthenium unit instead of the terminal site, 2) to electronically couple the individual ruthenium moieties across the bridging ligand, and 3) to explore how the degree of charge (and spin) delocalization depends on the overall oxidation state. To these ends we have prepared and investigated vinylbenzoatebridged diruthenium complexes $(\mathrm{RHC}=\mathrm{CH})(\mathrm{CO})\left(\mathrm{P}^{\prime} \mathrm{Pr}_{3}\right)_{2} \mathrm{Ru}(\mu-$ 4-OOCC $\left.{ }_{6} \mathrm{H}_{4}-\mathrm{CH}=\mathrm{CH}\right) \mathrm{RuCl}(\mathrm{CO})\left(\mathrm{P}^{i} \mathrm{Pr}_{3}\right)_{2}$ with substituents $\mathrm{R}=$ $\mathrm{Ph}$ (3a) or $\mathrm{CF}_{3}$ (3b) that differ in their electron richness, and the vinylpyridine-bridged $\mathrm{RuCl}_{2}\left(\eta^{6}-p\right.$-cymene $)\left(\mu-\mathrm{NC}_{5} \mathrm{H}_{4}-4\right.$ $\mathrm{CH}=\mathrm{CH}) \mathrm{RuCl}(\mathrm{CO})\left(\mathrm{P}^{i} \mathrm{Pr}_{3}\right)_{2}(3 \mathrm{c})\left(p\right.$-cymene $\left.=1-\mathrm{Pr}-4-\mathrm{Me}-\mathrm{C}_{6} \mathrm{H}_{4}\right)$. These are compared to their monoruthenium precursors $\mathrm{RuCl}(\mathrm{CH}=\mathrm{CHR})(\mathrm{CO})\left(\mathrm{P}^{\mathrm{P}} \mathrm{Pr}_{3}\right)_{2} \quad(\mathbf{1} \mathbf{a}, \mathbf{b})$ and $\mathrm{Ru}(\mathrm{CH}=\mathrm{CHR})\left(\eta^{2}-\right.$ $\left.\mathrm{OOCC}_{6} \mathrm{H}_{4} \mathrm{C} \equiv \mathrm{CH}-4\right)(\mathrm{CO})\left(\mathrm{P}^{i} \mathrm{Pr}_{3}\right)_{2} \quad\left(\mathrm{R}=\mathrm{Ph}\right.$ or $\left.\mathrm{CF}_{3}, \mathbf{2 a}, \mathbf{b}\right)$, $\mathrm{RuCl}_{2}\left(\eta^{6}-p\right.$-cymene) $\left(\mathrm{NC}_{5} \mathrm{H}_{4}-4-\mathrm{C} \equiv \mathrm{CH}\right) \quad(2 \mathrm{c})$, and the previously reported complex $\left(\mathrm{PPh}_{3}\right)_{2}(\mathrm{CO}) \mathrm{ClRu}\left(\mu-\mathrm{NC}_{5} \mathrm{H}_{4}-4-\mathrm{CH}=\mathrm{CH}\right)$ $\mathrm{RuCl}(\mathrm{CO})\left(\mathrm{P}^{i} \mathrm{Pr}_{3}\right)_{2}(\mathbf{3 d})^{3}$. It will be shown that upon judicious choice of the end group the primary oxidation can indeed be directed to the bridged diruthenium entity. We also show that the vinylpyridine bridge is much better suited to promoting electronic delocalization within the ruthenium-bridge-ruthenium entity than the vinylbenzoate one.

\section{Results and discussion}

$\mathrm{RuCl}\left(\mathrm{CH}=\mathrm{CHCF}_{3}\right)(\mathrm{CO}) \mathrm{Cl}\left(\mathrm{P}^{i} \mathrm{Pr}_{3}\right)_{2}(\mathrm{lb}), \mathrm{Ru}(\mathrm{CH}=\mathrm{CHR})\left(\eta^{2}-\right.$ OOCC $\left.\mathrm{H}_{4} \mathrm{C} \equiv \mathrm{CH}-4\right)(\mathrm{CO})\left(\mathrm{P}^{i} \mathrm{Pr}_{3}\right)_{2}\left(\mathrm{R}=\mathrm{Ph}(2 \mathrm{a})\right.$ or $\mathrm{CF}_{3} \mathrm{CH}=\mathrm{CH}$ (2b)) and $\mathrm{RuCl}_{2}\left(\eta^{6}-p\right.$-cymene $)\left(\mathrm{NC}_{5} \mathrm{H}_{4}-4-\mathrm{C} \equiv \mathrm{CH}\right)(2 \mathrm{c})$

Ruthenium vinyl complexes $(\mathrm{RCH}=\mathrm{CH}) \mathrm{Ru}(\mathrm{CO}) \mathrm{Cl}\left(\mathrm{P}^{i} \mathrm{Pr}_{3}\right)_{2}$ are easily prepared from the regio- and stereospecific insertion of terminal alkynes into the $\mathrm{Ru}-\mathrm{H}$ bond of the hydride complex 

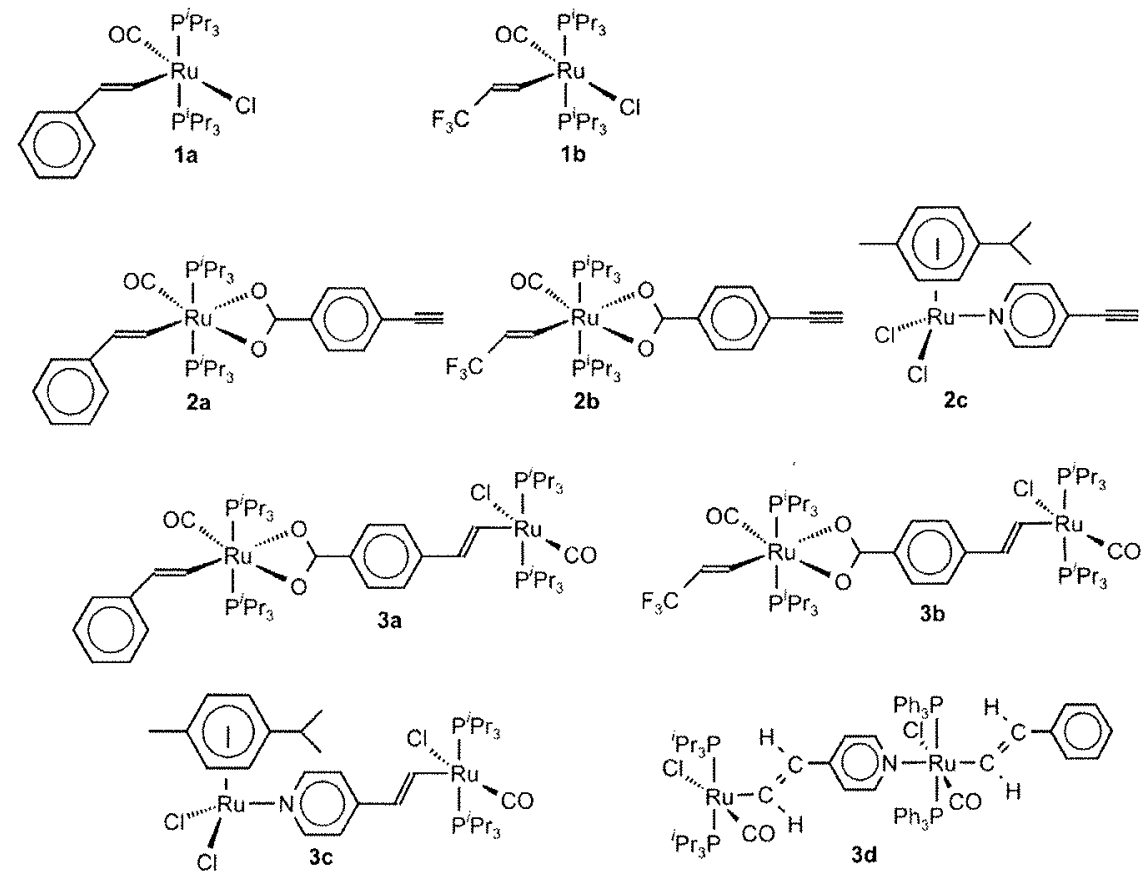

Chart 1 Vinylbenzoate- and vinylpyridine-bridged diruthenium complexes and their precursors.

$\mathrm{RuClH}(\mathrm{CO})\left(\mathrm{P}^{\mathrm{P}} \mathrm{Pr}_{3}\right)_{2}$. This so-called hydroruthenation proceeds in the anti-Markovnikov sense and provides vinyl complexes with a trans disposition of the metal atom and the substituent at the adjacent carbon atom. ${ }^{2,5-10}$ The styryl complex 1a has been previously reported, ${ }^{2,7-10}$ The trifluoropropenyl complex $1 \mathrm{~b}$ represents a vinyl complex with an electron withdrawing substituent at the vinyl ligand. It is easily available in high yield as an orange-red, microcrystalline solid by treating $\mathrm{RuClH}(\mathrm{CO})\left(\mathrm{P}^{i} \mathrm{Pr}_{3}\right)_{2}$ with trifluoropropyne gas in a $\mathrm{CH}_{2} \mathrm{Cl}_{2}$ solution. $\mathbf{1 b}$ is readily characterized as a vinyl complex by virtue of the characteristic low field signals of the vinyl protons at $\delta=9.02(\mathrm{Ru}-\mathrm{CH})$ and $5.20 \mathrm{ppm}(\mathrm{Ru}-\mathrm{CH}=\mathrm{CH})$. Each of these signals is split into a triplet of quartet of doublet pattern due to well-resolved ${ }^{3} J_{\mathrm{H} \cdot \mathrm{H}}$, ${ }^{n} J_{\mathrm{H}-\mathrm{P}}$ and ${ }^{n} J_{\mathrm{H}-\mathrm{F}}(n=3$ or 4$)$ couplings. The lower electron density at the ruthenium atom in $\mathbf{1 b}$ through introduction of the electron withdrawing $\mathrm{CF}_{3}$ substituent is reflected in the $\mathrm{CO}$ stretching energy of the ruthenium bonded carbonyl ligand $(v(\mathrm{CO})=$ $\left.1916 \mathrm{~cm}^{-1}\right)$. This band is blue-shifted when compared to styryl complex 1a $\left(v(\mathrm{CO}) 1908 \mathrm{~cm}^{-1}\right)$ or the related hexenyl complex $(n \mathrm{BuCH}=\mathrm{CH}) \mathrm{Ru}(\mathrm{CO}) \mathrm{Cl}\left(\mathrm{P}^{i} \mathrm{Pr}_{3}\right)_{2}\left(v(\mathrm{CO}) 1906 \mathrm{~cm}^{-1}\right){ }^{2}$ Attempts to obtain a similar complex from bulky 3,3-bis(trifluoromethyl)4,4,4-trifluorobutyne were not successful at room temperature or in refluxing $\mathrm{CH}_{2} \mathrm{Cl}_{2}$.

Chloride substitution was achieved by stirring complexes $\mathbf{1 a}, \mathbf{b}$ with a slight excess of sodium 4-ethynylbenzoate in THF. The latter reaction is strongly accelerated ( $10 \mathrm{~min}$ instead of $1 \mathrm{~h})$ in the presence of stoichiometric amounts of $\mathrm{TIPF}_{6}$ as a chloride scavenger. The conversion of the square pyramidal 16 valence electron vinyl complexes to their octahedral 18 valence electron benzoate derivatives is accompanied by a colour change from deep red (1a) or orange (1) to yellow. Ethynyl benzoate complexes $\mathbf{2 a , b}$ are characterized by strong absorptions of the carbonyl ligand at 1905 (2a) or $1914(\mathbf{2 b}) \mathrm{cm}^{-1}, \mathrm{C}=\mathrm{C}$ stretches of the vinyl ligand and
Table 1 Electrochemical properties of the investigated complexes $\left(\mathrm{CH}_{2} \mathrm{Cl}_{2} / 0.1 \mathrm{M} \mathrm{NBu}_{4} \mathrm{PF}_{6}\right)$

\begin{tabular}{|c|c|c|c|}
\hline Complex & $E_{1 / 2}{ }^{0 / 4} / \mathrm{V}^{a}\left(i_{\mathrm{p}, \text {,ev }} / i_{\mathrm{p}, \mathrm{f}}\right)^{b}$ & $E_{\mathrm{p}}^{+/ 2+} / \mathrm{V}^{a, c}$ & $E_{1 / 2}{ }^{+/ 2+} / \mathrm{V}^{a}\left(i_{\mathrm{p}, \mathrm{rev}} / i_{\mathrm{p}, \mathrm{r}}\right)^{b}$ \\
\hline $1 a^{2}$ & $0.28(0.98)$ & 0.80 & - \\
\hline 1b & $0.81^{c}(0.75)$ & n. $o$. & - \\
\hline $2 a$ & $0.12(1.0)$ & 1.23 & - \\
\hline $2 \mathrm{~b}$ & $0.66(0.93)$ & n. $o$. & - \\
\hline $2 c$ & $0.89(0.84)$ & n. o. & - \\
\hline $3 a$ & $0.09(1.0)$ & - & $0.43(1.0)$ \\
\hline $3 \mathrm{~b}$ & $0.34(0.98)$ & - & $0.73(0.8)$ \\
\hline $3 \mathbf{c}$ & $0.60(0.87)$ & - & $0.87(0.35)$ \\
\hline $3 \mathbf{d}^{3}$ & $0.23(0.98)$ & -_. & $0.685(0.7)$ \\
\hline
\end{tabular}

${ }^{a}$ All potentials are referenced to $\mathrm{E}_{1 / 2}\left(\mathrm{Cp}_{2} \mathrm{Fe}^{0 /+}\right)=0.00 \mathrm{~V} \cdot{ }^{b}$ Ratio of peak currents for the reverse and the forward wave at $y=0.1 \mathrm{~V} \mathrm{~s}^{-1}$ as determined by the method given in ref. $39^{\circ}$ Peak potential of the second, irreversible oxidation of the mononuclear styryl complexes.

the aryl substituents, the characteristic $\mathrm{C} \equiv \mathrm{C}$ and $\equiv \mathrm{CH}$ bands of the ethynyl function and the bands of the chelating benzoate at ca. 1520 and $1430 \mathrm{~cm}^{-1}$ (see Table 2). The splitting of the $\mathrm{RCOO}^{-}$ bands is in accord with the chelating $\mathrm{K}^{1}-\mathrm{O}, \mathrm{O}$ bonding mode.

Complexes $1 \mathrm{a}$ and $\mathbf{2 a}$ undergo a chemically reversible, yet electrochemically only quasireversible, oxidation as is indicated by peak-to-peak separations that exceed those of the ferrocene/ferrocenium standard by some 10 to $30 \mathrm{mV}$. For $\mathbf{1 b}$ and $\mathbf{2} \mathbf{b}$, additional distortions arise from the limited lifetimes of the associated radical cations, such that only part of the radical cations generated during the anodic forward scan can be reduced back in the cathodic reverse scan. Chloride substitution by ethynylbenzoate aids in their stabilization as can be inferred from the increase of the ratio between the reverse and forward peak currents $i_{\mathrm{p}, \mathrm{rev}} / i_{\mathrm{p}, \mathrm{forw}}$ (see Table 1 and Fig. S1 of the ESI $\dagger$ ). We also note that chloride substitution for ethynylbenzoate induces 
Table 2 IR stretching frequencies of the investigated complexes in their various oxidation states $\left(\mathrm{C}_{2} \mathrm{H}_{4} \mathrm{Cl}_{2}-1,2\right)$ and $\mathrm{G} 03 / \mathrm{PBE} 0$ calculated $\tilde{\mathrm{v}}(\mathrm{CO})$ (scaling factor 0.914). Calculated values are for $\mathrm{PMe}_{3}$ model complexes. Values for doubly oxidized model complexes pertain to their triplet ground states

\begin{tabular}{|c|c|c|c|c|c|c|}
\hline Complex & $\begin{array}{l}\tilde{v}(\mathrm{CO}) / \mathrm{cm}^{-1} \\
\text { Experimental }\end{array}$ & $\begin{array}{l}\tilde{v}(\mathrm{CO}) / \mathrm{cm}^{-1} \\
\text { Calculated }\end{array}$ & $\tilde{v}(\mathrm{COO}) / \mathrm{cm}^{-1}$ & $\tilde{v}\left(\mathrm{CH}_{\text {ary }}, \mathrm{CH}_{\text {vinyi }}\right) / \mathrm{cm}^{-1}$ & $\tilde{v}(\mathrm{C} \equiv \mathrm{C}) / \mathrm{cm}^{-1}$ & $\tilde{v}(\equiv \mathrm{CH}) / \mathrm{cm}^{-1}$ \\
\hline $1 \mathrm{a}$ & $1911(s)$ & 1911 & n. a. & $1595(\mathrm{w}), 1579(\mathrm{~m}), 1554(\mathrm{~m})$ & n. a. & n. a. \\
\hline $1 a^{+}$ & $1976(s)$ & 1971 & n. a. & $\begin{array}{l}1595(\mathrm{w}), 1579(\mathrm{~m}), 1576(\mathrm{~m}) \\
1554(\mathrm{~m})\end{array}$ & n. a. & n. a. \\
\hline $1 \mathrm{~b}$ & $1921(\mathrm{~s})$ & 1919 & n.a. & $1584(\mathrm{~m})$ & n. a. & n. a. \\
\hline $1 b^{+}$ & $1998(\mathrm{~s})$ & 1992 & n. a. & $1589(w)$ & n. a. & n. a. \\
\hline $2 \mathbf{a}$ & $1904(\mathrm{~s})$ & 1911 & $1525(\mathrm{~m})$ & $\begin{array}{l}1596(\mathrm{w}), 1578(\mathrm{~m}), 1554(\mathrm{~m}) \\
1483(\mathrm{~m})\end{array}$ & $2090(w)$ & $3307(w), 3290(w)$ \\
\hline $2 a^{+}$ & $1976(\mathrm{~s})$ & 1966 & $1510(\mathrm{~m})$ & $\begin{array}{l}1604(\mathrm{w}), 1575(\mathrm{~m}), 1497(\mathrm{~m}) \\
1497(\mathrm{w})\end{array}$ & $2086(w)$ & $3310(w), 3291(w)$ \\
\hline $\mathbf{2 b}$ & $1912(s)$ & 1917 & $1522(\mathrm{~m})$ & $1579(\mathrm{~m})$ & $2089(w)$ & $3307(w), 3290(w)$ \\
\hline $\mathbf{2 b}^{+}$ & $2001(\mathrm{~s})$ & 1986 & $1512(\mathrm{~m})$ & $1605(\mathrm{~m}), 1485(\mathrm{~m})$ & $2071(w)$ & $3309(w), 3291(w)$ \\
\hline $2 c$ & n. a. & n.a. & n. a. & $1610(s), 1540(w), 1490(w)$ & $2105(\mathrm{~m})$ & $3205(\mathrm{~m})$ \\
\hline $3 \mathbf{a}$ & $1914(\mathrm{~s}), 1901(\mathrm{~s})^{a}$ & 1914,1908 & $1509(\mathrm{~m})$ & $\begin{array}{l}1598(\mathrm{~m}), 1579(\mathrm{~m}), 1550(\mathrm{~s}) \\
1508(\mathrm{w}), 1483(\mathrm{~m})\end{array}$ & n. a. & n. a. \\
\hline $3 a^{+}$ & $1973(\mathrm{~s}), 1915(\mathrm{~s})^{a}$ & 1961,1925 & $1509(\mathrm{~m})$ & $\begin{array}{l}1598(\mathrm{~m}), 1575(\mathrm{~m}), 1543(\mathrm{~m}) \\
1509(\mathrm{~m}), 1483(\mathrm{~m})\end{array}$ & n. a. & n. a. \\
\hline $3 a^{2+}$ & $1979(\mathrm{~s})$ & 1974,1983 & $1497(\mathrm{~m})$ & $\begin{array}{l}1599(\mathrm{w}), 1578(\mathrm{w}), 1542(\mathrm{w}) \\
1506(\mathrm{~m}), 1483(\mathrm{~m})\end{array}$ & n. a. & n. a. \\
\hline $\mathbf{3 b}$ & $19\left[4(s), 1908(s)^{a}\right.$ & 1916,1914 & $1508(\mathrm{~m})$ & $\begin{array}{l}1599(\mathrm{~m}), 1579(\mathrm{~m}), 1549(\mathrm{~m}) \\
1500(\mathrm{w})\end{array}$ & n. a. & n. a. \\
\hline $3 \mathbf{b}^{++}$ & $1979(\mathrm{~s}), 1917(\mathrm{~s})$ & 1959,1933 & $1495(\mathrm{~m})$ & $1581(\mathrm{~m}), 1520(\mathrm{w})$ & n. a. & n. a. \\
\hline $3 \mathbf{b}^{2+}$ & $1989(\mathrm{br})$ & 1989,1977 & n. o. & $1610(\mathrm{~m})$ & n. a. & n. a. \\
\hline $3 \mathbf{c}$ & $1920(s)$ & 1920 & n. a. & $1610(\mathrm{~m}), 1552(\mathrm{~s}), 1524(\mathrm{~s})$ & n. a. & n. a. \\
\hline $3 c^{+}$ & $1932(s)$ & 1940 & n. a. & $\begin{array}{l}1636(\mathrm{~m}), 1544(\mathrm{~m}), 1525(\mathrm{~m}) \\
1499(\mathrm{~s})\end{array}$ & n. a. & n. a. \\
\hline $3 d^{3}$ & $1919(s)$ & 1936,1910 & n. a. & $1608(\mathrm{~m}) 1.554(\mathrm{~s}), 1527(\mathrm{~m})$ & n. a. & n. a. \\
\hline $3 \mathbf{d}^{+}$ref. 3 & $1970(s), 1933(s)$ & 1966,1948 & n. a. & $1637(\mathrm{~s}), 1595(\mathrm{w}), 1528(\mathrm{~s})$ & n. a. & n. a. \\
\hline $3 \mathbf{d}^{2+}$ ref. 3 & $1988(s)$ & 2009,2002 & n. a. & $1637(\mathrm{~m})$ & n. a. & n. a. \\
\hline
\end{tabular}

a $150 \mathrm{mV}$ negative shift of the one-electron oxidation potential (Table 1). This provides some evidence for higher electron richness of the 18 valence electron systems when compared to their 16 valence electron counterparts. One has to bear in mind, though, that electrochemically measured redox-potentials are subject to several other contributions such as ion pairing and redox-induced changes of solvation energies such that there is no direct correlation between solution redox potentials and the actual HOMO energies. As one might expect from the potential decomposition schemes promoted by Pickett, Pombeiro and Lever, the potential shift arising from chloride versus benzoate substitution is nearly identical for both pairs of complexes, $\mathbf{1 a}, \mathbf{b}$ and $\mathbf{2 a}, \mathbf{b} .{ }^{11-14}$

The 4-ethynylpyridine substituted $p$-cymene complex $2 \mathrm{c}$ was synthesized from the chloro bridged $\left\{\operatorname{RuCl}_{2} \text { ( } p \text {-cymene) }\right\}_{2}$ dimer by established procedures (i.e. by stirring a slurry of the dimer and a slight excess of the pyridine ligand in THF ${ }^{15}$ and accordingly characterized by the low field AB doublets of the 4-substituted pyridine and the alkyne proton signal at $3.25 \mathrm{ppm}$, the alkyne carbon signals in ${ }^{13} \mathrm{C} N \mathrm{NMR}$ at $79.5(\equiv \mathrm{CH})$ and $83.4(\mathrm{C} \equiv \mathrm{CH})$, and by the $\mathrm{C} \equiv \mathrm{C}$ and $\equiv \mathrm{CH}$ bands in the IR spectra. This complex undergoes a chemically partially reversible one-electron oxidation $\left(i_{\mathrm{p}, \mathrm{rev}} / i_{\mathrm{p}, \mathrm{forw}}=0.84\right.$ at $\left.v=0.1 \mathrm{~V} \mathrm{~s}^{-1}\right)$ at $+0.89 \mathrm{~V}$ against the ferrocene/ferrocenium standard (Table 1).

Oxidation of the mononuclear styryl complexes $1 \mathbf{b}, \mathbf{2 a}$ and $2 \mathrm{~b}$ inside a transparent thin-layer electrolysis cell ${ }^{16}$ with $\mathrm{CaF}_{2}$ windows leads to a blue shift of the prominent carbonyl band. This shift reflects the loss of electron density at the metal atom upon oxidation and relates to the metal contribution to the "redox-orbital" which is primarily involved in the redox process. The metal contribution is expected to increase with increasing electron richness of the $\left\{\mathrm{Ru}(\mathrm{CO})(\mathrm{L})\left(\mathrm{PR}_{3}\right)_{2}\right\}$ moiety, with smaller spatial extension of the vinyl ligand's $\pi$-system and with decreasing energies of the vinyl ligand's $\pi$-orbitals. ${ }^{2}$ The results of this study conform to these qualitative expectations (see Table 2). Thus, the $\mathrm{CO}$ band shift experienced by the triffuoropropenyl complex $1 \mathrm{~b}$ of $77 \mathrm{~cm}^{-1}$ surpasses that of the styryl complex 1a of $65 \mathrm{~cm}^{-1}$. The same reasoning also explains why the sixcoordinated benzoate complexes $\mathbf{2} \mathbf{a}, \mathbf{b}$ display a larger $\mathrm{CO}$-band shift $\left(89 \mathrm{~cm}^{-1}\right.$ in $\mathbf{2 b}, 77 \mathrm{~cm}^{-1}$ in $\mathbf{2 a}$, see Fig. 1 and Fig. S2 and S3 of the ESIt) than their less electron-rich five-coordinated chloro substituted precursors. We note here that the moderate $\mathrm{CO}$ band shifts upon oxidation when compared to the 100 to $150 \mathrm{~cm}^{-1}$ shifts of more "conventional" carbonyl complexes" (c.f. $\Delta \tilde{\mathrm{v}}(\mathrm{CO}) \sim 110 \mathrm{~cm}^{-1}$ for complexes $\left.\mathrm{Ru}(\mathrm{CO})_{3}\left(\mathrm{PR}_{3}\right)_{2}{ }^{0 / 4}\right)^{18,19}$ are a general asset of such vinyl ruthenium complexes and arise from the non-innocent character of the vinyl ligand ${ }^{1-5}$ and, possibly, from the orthogonality of the $\mathrm{Cl}-\mathrm{Ru}(\mathrm{CO})$ and the vinyl-ruthenium $\pi$-systems. Further spectroscopic changes upon oxidation include slight shifts of the $\mathrm{C} \equiv \mathrm{C}$ and the $\equiv \mathrm{CH}$ stretching frequencies of the free ethynyl group and of the $\mathrm{C}=\mathrm{C}$ and $\mathrm{COO}$ stretching frequencies of the vinyl, styryl and vinylbenzoate ligands (see Table 2). Of particular note is a red shift of $v_{s}(\mathrm{COO})$ of the benzoate ligand of $15(\mathbf{2 a})$ or $10 \mathrm{~cm}^{-1}(\mathbf{2 b})$ upon oxidation. The stabilizing effect of the ethynylbenzoate ligand on the associated radical cation $\mathbf{2 b}^{\circ}$ + already seen in the voltammetric studies also becomes evident in IR spectroelectrochemistry. While the oxidation of $1 \mathrm{~b}$ produces larger 


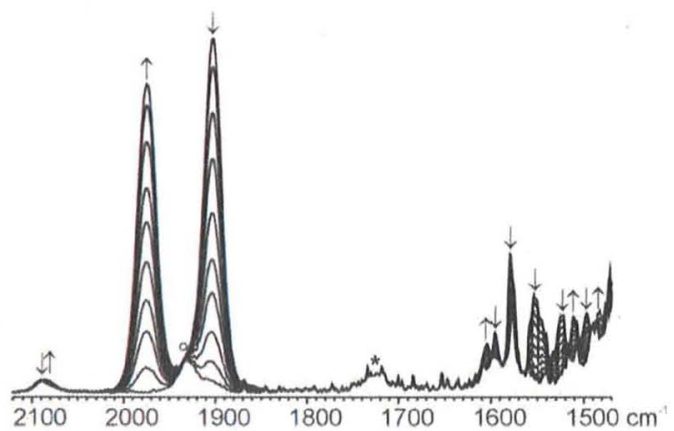

Fig. 1 Spectroscopic changes in the infrared during electrochemical oxidation of complex $2 \mathrm{a}\left(\mathrm{DCE} / \mathrm{NBu}_{4} \mathrm{PF}_{6}(0.2 \mathrm{M})\right.$ at r. t.). The star symbol indicates artefacts due to solvent degradation; the circle symbol indicates the signal of a decomposition product.

quantities of decomposition products with $\mathrm{CO}$ bands at 1979 and $1958 \mathrm{~cm}^{-1}$ in addition to the associated radical cation $\mathbf{1 \mathbf { b } ^ { + }}$, radical cation $\mathbf{2} \mathbf{b}^{\circ}+$ showed a superior lifetime with only minor degradation (see Fig. S2 and S3 of the ESI $\dagger$ ). Styryl complex 2a produces a rather stable radical cation such that the spectroscopic yield of regenerated $\mathbf{2 a}$ was $95 \%$ after a full oxidation-reduction cycle.

Quantum chemical calculations on simplified model complexes $\mathbf{1} \mathbf{a}^{\mathrm{Me}}, \mathbf{1} \mathbf{b}^{\mathrm{Me}}, \mathbf{2} \mathbf{a}^{\mathrm{Me}}$ and $\mathbf{2} \mathbf{b}^{\mathrm{Me}}$ bearing $\mathrm{PMe}_{3}$ instead of $\mathrm{P}^{i} \mathrm{Pr}_{3}$ ligands reproduce the trends of $\mathrm{CO}$ band positions and oxidation-induced band shifts (Table 2). Replacement of $\mathrm{P}^{i} \mathrm{Pr}_{3}$ by $\mathrm{PMe}_{3}$ ligands has been shown to provide reasonable estimates for the $v(\mathrm{CO})$ values as follows from the comparison of our results on $\mathrm{RuCl}\left(\mathrm{CH}=\mathrm{CH}^{n} \mathrm{Bu}\right)(\mathrm{CO})\left(\mathrm{PMe}_{3}\right)_{2}{ }^{0 /+}$ and $\mathrm{RuCl}\left(\mathrm{CH}=\mathrm{CH}^{n} \mathrm{Bu}\right)(\mathrm{CO})\left(\mathrm{P}^{i} \mathrm{Pr}_{3}\right)_{2}{ }^{0 /+}$, where $v(\mathrm{CO})$ values differ by no more than $3 \mathrm{~cm}^{-1}{ }^{2}$ Fig. 2 depicts the calculated frontier orbitals of the model systems. In particular, the frontier orbitals of complex $\mathbf{~ b ~}^{\mathrm{Me}}$ closely resemble those of the related hexenyl model complex $\mathrm{RuCl}\left(\mathrm{CH}=\mathrm{CHC}_{4} \mathrm{H}_{9}\right)(\mathrm{CO})\left(\mathrm{PMe}_{3}\right)_{2}{ }^{2}$ with the expected energy lowering of the vinyl based orbitals due to the electron withdrawing $\mathrm{CF}_{3}$ substituent and the concomitant higher metal contribution to the HOMO ( $54 \%$ in $1 \mathrm{~b}^{\mathrm{Me}}$ as compared to $46 \%$ in $\left.\mathrm{RuCl}\left(\mathrm{CH}=\mathrm{CHC}_{4} \mathrm{H}_{9}\right)(\mathrm{CO})\left(\mathrm{PMe}_{3}\right)_{2}\right){ }^{2}$ We also note that the magnitude of the calculated oxidation-induced $\mathrm{CO}$ band shifts increase with increasing metal contribution to the HOMO orbitals of the neutrals (see Table 6 ) or to the $\beta$-LUSOs of their associated radical cations (see Fig. 4).

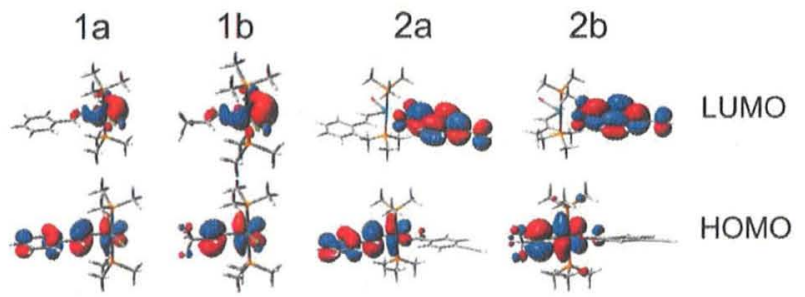

Fig. 2 Frontier molecular orbitals (FMOs) of model complexes $\mathbf{1 a}^{\mathrm{Me}}$, $\mathbf{1 b ^ { \mathrm { Me } }}, \mathbf{2 \mathbf { a } ^ { \mathrm { Me } }}$, and $\mathbf{2} \mathbf{b}^{\mathrm{Me}}$.

UV/Vis/NIR spectroscopic data of the complexes are compiled in Table 3. Following our earlier work on similar vinyl complexes $^{2,5}$ and the present calculations on $1 \mathrm{a}^{\mathrm{Mc}}, 1 \mathbf{b}^{\mathrm{Mc}}, 2 \mathrm{a}^{\mathrm{Me}}$ and $2 \mathbf{b}^{\mathrm{Me}}$, the lowest energy band in the electronic spectra of the mononuclear five-coordinated vinyl complexes involves the
Table 3 Electronic spectra of the complexes in their various oxidation states in $\mathrm{C}_{2} \mathrm{H}_{4} \mathrm{Cl}_{2}-1,2$

\begin{tabular}{|c|c|}
\hline & $\lambda_{\max } / \mathrm{nm}\left(\varepsilon_{\max } / \mathrm{M}^{-1} \mathrm{~cm}^{-1}\right)$ \\
\hline 1a & 272 (sh, 1750), 306 (3200), $381(580), 510(290)^{2}$ \\
\hline $1 \mathrm{a}^{+}$ & 272 (sh, 1800), $368(2270), 388(2640), 633(1145), 875(280)^{2}$ \\
\hline 1b & $384(1570), 470(400)$ \\
\hline $1 \mathbf{b}^{+}$ & 290 (6570), $384(2380), 470(740), 601(240), 1210(200)$ \\
\hline $2 a$ & $258(25000), 310(17900), 386(2150), 404(1290)$ \\
\hline $2 \mathrm{a}^{+}$ & $258(27500), 276(23300), 386(1270), 403(10100), 664(3230)$ \\
\hline $2 \mathrm{~b}$ & $325(8450)$ \\
\hline $2 \mathbf{b}^{+}$ & $325(6550), 536(1330), 1207(600)$ \\
\hline $2 \mathrm{c}$ & $326(5320), 427(910)$ \\
\hline $2 c^{+}$ & $427(1900), 596(390)$ \\
\hline 3a & $358(28670), 492(1750)$ \\
\hline $3 \mathrm{a}^{+}$ & $262(24000), 385(32600), 666(5800)$ \\
\hline $3 \mathrm{a}^{2+}$ & 291 (16650), 289 (27850), $408(28000), 660$ (9700) \\
\hline $3 \mathrm{~b}$ & 359 (27900), $500(880)$ \\
\hline $3 \mathbf{b}^{+}$ & $\begin{array}{l}297(12000), 395(19100), 422(20600), 500(2100), 668(5250), 1020 \\
(2100)\end{array}$ \\
\hline $3 \mathrm{c}$ & $294(7360), 374(29000)$ \\
\hline $3 c^{+}+$ & $274(10370), 425(19800)$ \\
\hline
\end{tabular}

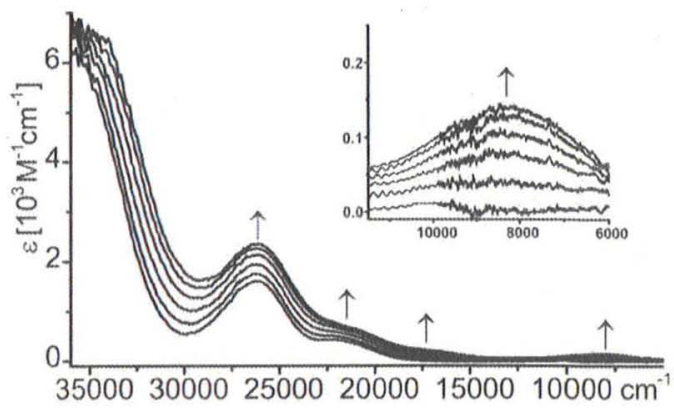

Fig. 3 Changes in the UV/Vis/NIR spectra of complex $\mathbf{1 b}$ upon oxidation to $1 \mathbf{b}^{+}\left(\mathrm{DCE} / \mathrm{NBu}_{4} \mathrm{PF}_{6}(0.2 \mathrm{M})\right.$ at r. t.); inset: low energy region magnified.

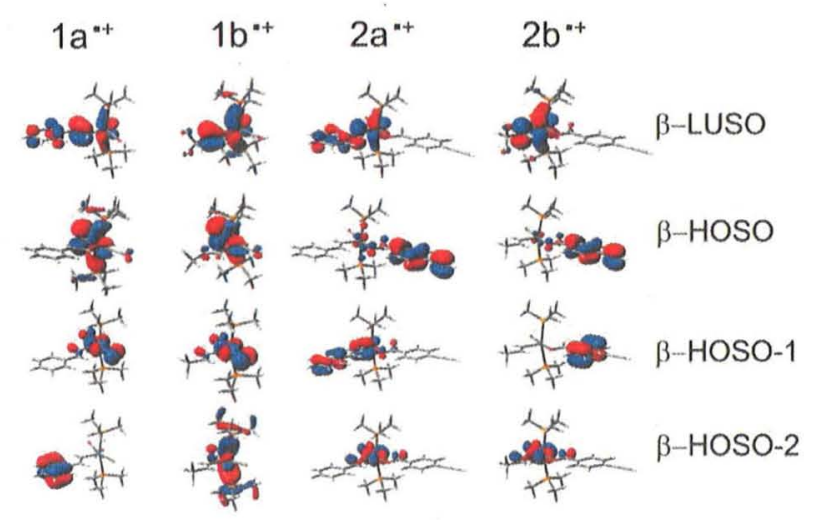

Fig. 4 Orbitals $\beta$-HOSO-2 to $\beta$-LUSO of model complexes $1 \mathbf{a}, \mathbf{b}^{\mathrm{Me}+}$ and $2 \mathbf{a}, \mathbf{b}^{\mathrm{Me}+}$.

excitation of an electron from the mixed metal/vinyl $\pi$-HOMO to the largely metal/phosphine co-ligand based LUMO. This band, though usually only weak, provides these complexes with their brilliant purple to orange-red coloration. The LUMOs of the six-coordinated vinyl complexes $\mathrm{Ru}(\mathrm{CH}=\mathrm{CHR})\left(\mathrm{COOC}_{6} \mathrm{H}_{4} \mathrm{CCH}\right.$ $4)(\mathrm{CO})\left(\mathrm{PR}_{3}^{\prime}\right)_{2}$ are, however, dominated by the ethynylbenzoate ligand such that the lowest energy band assumes a mixed vinyl ligand/metal $\rightarrow$ benzoate charge-transfer character. Experimental 
Table 4 Selected G03/PBE0/CPCM $\left(\mathrm{C}_{2} \mathrm{H}_{4} \mathrm{Cl}_{2}-1,2\right)$ calculated lowest allowed TD-DFT transitions for neutral complexes and the radical cations of monoruthenium complexes with oscillator strengths larger than 0.003

$\lambda_{\text {miax }} / \mathrm{nm}$ (oscillator strength)

$1 a^{\text {Me }} 301(0.014), 307(0.013), 387(0.031), 503(0.007)$

$1 \mathrm{a}^{\mathrm{Me}+} 368(0.072), 374(0.294), 494(0.033), 560(0.208), 750(0.007)$

$1 b^{\text {Me }} 380(0.028), 432(0.014)$

$\mathbf{1 b}^{\mathrm{Me}+} 264(0.163), 286(0.025), 365(0.032), 407(0.053), 543(0.004), 1035$ $(0.004)$

$2 a^{\text {Me }} 296(0.520), 299(0.264), 363(0.007), 399(0.039)$

$2 \mathbf{a}^{\text {Me'+ }} 278(0.872), 294(0.0723), 346(0.258) 377(0.232), 470(0.033), 604$ $(0.230) 678(0.003)$

$2 b^{\text {Me }} \quad 282(0.470), 332(0.010), 341(0.058)$

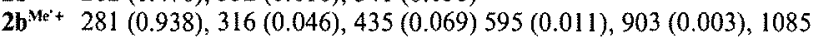
$(0.0002)$

$2 \mathrm{c}^{\mathrm{Me}} \quad 314(0.142), 360(0.012), 407(0.006), 482(0.006)$

$3 \mathrm{a}^{\mathrm{Me}} \quad 332(1.101), 362 .(0.172), 385(0.045) 502(0.006)$

$3 b^{\text {Me }} 338(1.160), 386(0.046) 500(0.006)$

$3 \mathrm{c}^{\mathrm{Me}} 334(0.874) 348(0.072) 379(0.053) 450(0.010)$

data may be compared to the calculated transition wavelengths and oscillator strengths of singlet excitations within neutral model complexes as they are provided in Table 4. This comparison shows that TD-DFT calculated values reproduce the differences between the experimental spectra of complexes $\mathbf{1 a}, \mathbf{1} \mathbf{b}$ and $\mathbf{2 a}, \mathbf{2 b}$ qualitatively well.

Oxidation of the mononuclear vinyl complexes to their radical cations induces the growth of characteristic low-energy absorption bands in the range of 16700 to $15000 \mathrm{~cm}^{-1}(600$ to $665 \mathrm{~nm})$ and near $25000 \mathrm{~cm}^{-1}(400 \mathrm{~nm})$ along with a weak absorption near $11000 \mathrm{~cm}^{-1}(900 \mathrm{~nm})$ for oxidized styryl complexes $1 \mathbf{a}^{+}, \mathbf{2 a}^{*}$ (Fig. $\mathrm{S} 4$ of the ESI $\dagger)$ or at $c a .8250 \mathrm{~cm}^{-1}(1210 \mathrm{~nm})$ for complexes $1 \mathrm{~b}^{+}$, $2 \mathrm{~b}^{+}$(see Fig. 3 and S4, S5 of the ESI $\dagger$ ). The TD-DFT calculations reproduce the shift of the lowest lying transitions to longer wavelengths upon oxidation as well as the shift to longer wave-

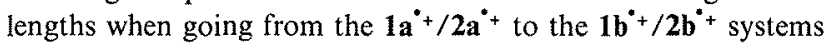
(Table 4). The low energy bands are composed of several individual transitions with a large contribution from the weakly allowed $\beta$ HOSO $\rightarrow \beta$-LUSO transition, $i$. $e$. from a ruthenium/phosphine$(\mathbf{1 a}, \mathbf{1 b})$ or a benzoate-based $(\mathbf{2} \mathbf{a}, \mathbf{2 b})$ donor orbital into a oneelectron orbital that is delocalized over the metal/vinyl entity (see Fig. 4). The band in the 600 to $665 \mathrm{~nm}$ range involves transitions from lower-lying likewise delocalized orbitals $\beta$-HOSO-1 and $\beta$-HOSO-2 to the same acceptor orbital. Introduction of an acceptor substituent at the alkenyl ligand produces a low-energy shift of the Vis/NIR transitions. This is illustrated by comparing the radical cation $1 \mathbf{b}^{+}$with $\lambda_{\max }=601$ and $1210 \mathrm{~nm}$ to the oxidized hexenyl complex $\left[\mathrm{RuCl}\left(\mathrm{CH}=\mathrm{CHC}_{4} \mathrm{H}_{9}\right)(\mathrm{CO})\left(\mathrm{P}^{i} \operatorname{Pr}_{3}\right)_{2}\right]^{++}$ with $\lambda_{\max }=508$ and $980 \mathrm{~nm}^{2}$ Radical cation $2 \mathrm{c}^{\circ}+$ finally features two moderately intense absorptions at 427 and $596 \mathrm{~nm}$ which are of pyridine or cymene ligand-to-metal charge-transfer character (Fig. S6 of the ESI †).

In keeping with previous results on closely related vinyl complexes, ${ }^{2}$ the radical cations of styryl complexes $\mathbf{1 a}^{+}$and $\mathbf{2 a}^{*}$ are EPR active in fluid solution. Their $g_{\text {iso }}$ values deviate only slightly from the free electron value $g_{e}$ of 2.0023 , indicating their dominant organic character. Cooling to liquid nitrogen temperatures leads to axial spectra with a small g-tensor splitting of ca. 0.03 (Fig. 5 and Table 5). Radical cations derived from the trifluoropropenyl-substituted complexes $\mathbf{1 b}$ and $\mathbf{2} \mathbf{b}$, however, are EPR silent under ambient conditions and exhibit a somewhat
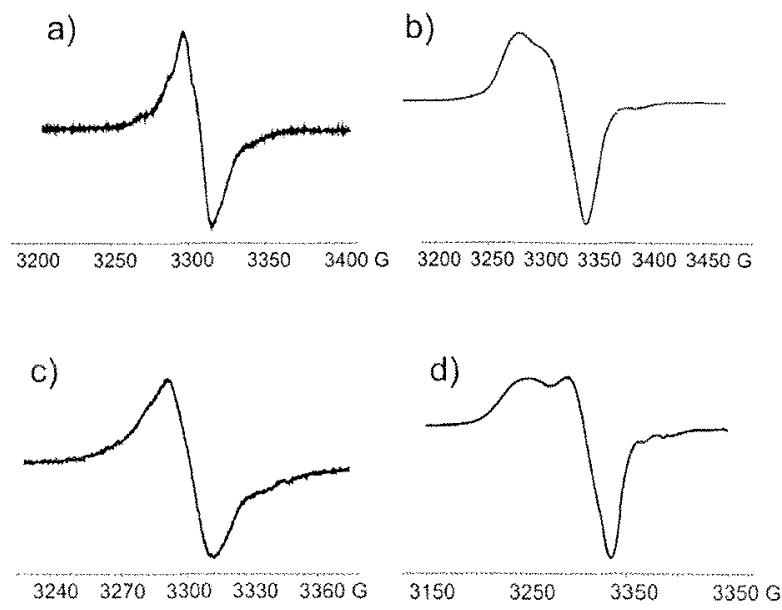

Fig. 5 EPR spectra of in situ electrogenerated $2^{\mathbf{a}^{+}}$and $\mathbf{3 b}^{+}$in $\mathrm{CH}_{2} \mathrm{Cl}_{2} / \mathrm{NBu}_{4} \mathrm{PF}_{6}(0.2 \mathrm{M})$. a) $2 \mathbf{a}^{+}$at r.t. and b) at $T=110 \mathrm{~K}$; c) $3 \mathbf{b}^{+}$ at r. t. and d) at $T=110 \mathrm{~K}$.

larger g-tensor anisotropy in a frozen glass (see Fig. S7 of the ESI†). No EPR signal was detected for in situ generated radical cation $2 \mathrm{c}^{\circ}$ at both $\mathrm{r}$. $\mathrm{t}$. and $100 \mathrm{~K}$. Oxidized half-sandwich ruthenium complexes seem to be only EPR active under these conditions when there are large ligand contributions to the SOMO, ${ }^{20-22}$ a likely consequence of rapid spin-lattice relaxation. These distinctive features can be utilized to determine the primary oxidation site in dinuclear complexes $3 \mathbf{b}, \mathbf{c}$ featuring terminal $\left\{\mathrm{RuCl}_{2}(p\right.$-cymene $\left.)\right\}$ or $\left\{\mathrm{Ru}\left(\mathrm{CH}=\mathrm{CHCF}_{3}\right)(\mathrm{CO})\left(\mathrm{P}^{i} \mathrm{Pr}_{3}\right)_{2}\right\}$ sites.

\section{Vinylbenzoate- and vinylpyridine-bridged dinuclear complexes $3 \mathrm{a}$,} $3 \mathrm{~b}$, and $3 \mathrm{c}$

Treatment of ethynylpyridine- or ethynylbenzoate-functionalized complexes $2 \mathrm{a}-\mathrm{c}$ with the hydride complex $\mathrm{RuClH}(\mathrm{CO})\left(\mathrm{P}^{i} \mathrm{Pr}_{3}\right)_{2}$ affords an easy, high-yield access to dinuclear complexes $\mathbf{3 a -}$ c with a vinylpyridine or vinylbenzoate bridge spanning two ruthenium atoms (Chart 1). The NMR-spectra of complexes $\mathbf{3 a}, \mathbf{b}$ contain the characteristic signal sets of two different vinyl moieties which can be assigned on the basis of resolved $J_{\mathrm{HF}}$ or $J_{\mathrm{CF}}$ couplings (3b) or of $2 \mathrm{D}$ NMR experiments including HMBC and HSQC pulse sequences, thus confirming their proposed structures. An interesting trend we observed is that the less electron rich vinyl ligand has the $\mathrm{Ru}-\mathrm{CH}$ proton signal at a lower and the $\mathrm{Ru}-\mathrm{CH}=\mathrm{CH}$ signal at a higher field and thus displays the larger shift difference for the vinyl protons. This may indicate a stronger polarization of the vinyl ruthenium moiety. Similar trends pertain to the ${ }^{13} \mathrm{C}$ NMR signals of $3 \mathbf{b}$ with the ruthenium-bonded $\alpha$-carbon of the 1,1,1-trifluoropropenyl ligand resonating at a lower field (173.2 versus $157.0 \mathrm{ppm})$ and the remote $\beta$-carbon at a higher field (119.5 versus $134.3 \mathrm{ppm}$ ) when compared to the bridging vinylbenzoate ligand. The resonance signals of the bridging vinylbenzoate ligand are at rather similar fields for complexes $\mathbf{3} \mathbf{a}, \mathbf{b}$ with a slightly higher shift difference of $22.7 \mathrm{ppm}$ for complex $\mathbf{3 b}$ when compared to 22.1 ppm in the more electron-rich complex 3a. Larger shift differences are observed for the vinylpyridine-bridged complexes $3 \mathrm{c}$ and 3d that differ in the pyridine coordinated end-groups, i.e. the electron-poor $\left\{\mathrm{RuCl}_{2}(p\right.$-cymene $\left.)\right\}(\delta(\mathrm{CH})=9.73$, 
Table 5 EPR spectra of in situ generated radical cations $\left(\mathrm{CH}_{2} \mathrm{Cl}_{2} / \mathrm{NBu}_{4} \mathrm{PF}_{6}\right)$

\begin{tabular}{|c|c|c|c|c|}
\hline & Experimental & & Calculated & \\
\hline $\begin{array}{l}\text { Compound } \\
1 \mathbf{a}^{+}\end{array}$ & $\begin{array}{l}g_{\mathrm{iss}}(T=293 \mathrm{~K}) \\
2.0448\end{array}$ & $g_{1}, g_{i},<g_{i s o}>\left(A_{k}\right)(T=110 \mathrm{~K})$ & $\begin{array}{l}g_{\text {iso }} \\
2.039\end{array}$ & $\begin{array}{l}g_{1}, g_{2}, g_{3}\left(\Delta_{3}\right) \\
2.063,2.031,2.022(0.041)\end{array}$ \\
\hline $1 b^{+}$ & n. o. & $2.047,2.014<2.036>(0.033)$ & 2.069 & $2.142,2.048,2.016(0.126)$ \\
\hline $2 a^{+}$ & 2.0476 & $2.066,2.038<2.057>(0.028)$ & 2.041 & $2.065,2.035,2.022(0.043)$ \\
\hline $2 b^{+}$ & n. o. & $2.070,2.035<2.060>(0.035)$ & 2.057 & $2.102,2.058,2.011(0.091)$ \\
\hline $3 a^{+}$ & 2.0492 & 2.0199 & 2.042 & $2.053,2.040,2.032(0.021)$ \\
\hline $3 b^{+}$ & 2.0506 & $2.088,2.044<2.073>(0.044)$ & 2.050 & $2.081,2.058,2.040(0.041)$ \\
\hline $3 d^{+3}$ & - & $\begin{array}{l}2.0484,2.0147<2.0372> \\
(0.0337)\end{array}$ & - & 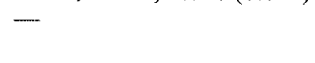 \\
\hline
\end{tabular}

Table 6 DFT G03/PBE0 calculated one-electron energies and compositions of selected frontier molecular orbitals of the mononuclear and dinuclear complexes $1 \mathbf{a}^{\mathrm{Me}}, \mathbf{1} \mathbf{b}^{\mathrm{Me}}, \mathbf{2} \mathbf{a}^{\mathrm{Me}}, \mathbf{2} \mathbf{b}^{\mathrm{Me}}, \mathbf{2} \mathbf{c}^{\mathrm{Mc}}, \mathbf{3 \mathbf { a } ^ { \mathrm { Me } }}, \mathbf{3 \mathbf { b } ^ { \mathrm { Me } }}$, and $\mathbf{3} \mathbf{c}^{\mathrm{Me}}$ expressed in terms of composing fragments

\begin{tabular}{|c|c|c|c|c|c|c|}
\hline Complex & MO & $E / \mathrm{eV}$ & $\mathrm{Vi}^{a}$ & Rul & Bridge $^{b}$ & $\mathrm{Ru} 2$ \\
\hline \multirow[t]{2}{*}{$1 a^{\mathrm{Me}}$} & LUMO & -1.36 & 13 & 59 & - & - \\
\hline & HOMO & -5.26 & 68 & 28 & - & - \\
\hline \multirow[t]{2}{*}{$1 b^{\mathrm{Mc}}$} & LUMO & -1.59 & 13 & 59 & - & - \\
\hline & HOMO & -6.12 & 38 & 54 & - & - \\
\hline \multirow[t]{2}{*}{$2 a^{M e}$} & LUMO & -1.41 & 0 & 1 & 99 & - \\
\hline & HOMO & -5.07 & 67 & 32 & 1 & - \\
\hline \multirow[t]{2}{*}{$2 \mathbf{b}^{\mathrm{Me}}$} & LUMO & -1.50 & 0 & 1 & 98 & - \\
\hline & HOMO & -5.85 & 35 & 61 & 4 & - \\
\hline \multirow[t]{2}{*}{$2 c^{\mathrm{Me}}$} & LUMO & -1.99 & - & 2 & 97 & - \\
\hline & HOMO & -5.89 & - & 39 & 1 & - \\
\hline \multirow[t]{3}{*}{$3 a^{\mathrm{Me}}$} & LUMO & -1.51 & 0 & 0 & 13 & 59 \\
\hline & HOMO & -4.91 & 65 & 30 & 2 & 0 \\
\hline & HOMO-1 & -5.43 & 1 & 1 & 65 & 27 \\
\hline \multirow[t]{3}{*}{$3 b^{\mathrm{Me}}$} & LUMO & -1.54 & 0 & 0 & 12 & 60 \\
\hline & HOMO & -5.46 & 3 & 7 & 61 & 25 \\
\hline & HOMO-1 & -5.72 & 33 & 50 & 8 & 3 \\
\hline \multirow[t]{3}{*}{$3 \mathrm{c}^{\mathrm{Mc}}$} & LUMO & -1.77 & 0 & 0 & 13 & 59 \\
\hline & HOMO & -5.65 & - & 38 & 2 & 0 \\
\hline & HOMO-I & -5.85 & - & 19 & 40 & 22 \\
\hline HOMO- & -5.86 & - & 29 & 4 & 1 & \\
\hline
\end{tabular}

${ }^{a} \mathrm{Vi}=\mathrm{CH}=\mathrm{CHR}$ ligand attached to the terminal $\mathrm{Ru} l$ site. ${ }^{b}$ Bridge $=4$ ethynylbenzoate (1a,b and $\mathbf{2} \mathbf{a}, \mathbf{b}), 4$-ethynylpyridine (2c), 4-vinylbenzoate $(3 a, b)$ or 4-vinylpyridine $(3 c)$.

$\left.6.05 \mathrm{ppm}, \delta\left(\mathrm{C}_{\text {vinyl }}\right)=170.3,130.9 \mathrm{ppm}\right)$ versus the electronrich $\left\{\mathrm{RuCl}(\mathrm{PhCH}=\mathrm{CH})(\mathrm{CO})\left(\mathrm{PPh}_{3}\right)_{2}\right\}(\delta(\mathrm{CH})=9.28,5.80 \mathrm{ppm}$, $\left.\delta\left(\mathrm{C}_{\text {vinyl }}\right)=155.4,138.4 \mathrm{ppm}\right)$ moieties. This increased sensitivity to the nature of the terminal metal moiety reflects the superior conjugative properties of vinylpyridine when compared to vinylbenzoate as the bridging ligand.

Despite the presence of two electronically distinct carbonyl ruthenium moieties, the IR spectra of complexes $\mathbf{3 a}, \mathbf{b}$ display only a single composite $\mathrm{CO}$ band. This band is somewhat broader than that of complex $3 \mathrm{c}$ with only one such $\mathrm{Ru}(\mathrm{CO})$ subunit. Deconvolution into two overlapping $\mathrm{CO}$ bands of about equal peak areas and band widths similar to those observed in precursors $\mathbf{2 a}, \mathbf{b}$ and in $\mathbf{3 c}$ resulted in the values given in Table 2 . Table 2 also includes other characteristic arene and vinyl $\mathrm{C}=\mathrm{C}$ and $\mathrm{COO}$ vibrations. IR bands at $c a .1610$ and $1550 \mathrm{~cm}^{-1}$ of $3 \mathrm{c}$ which are assigned to the bridging vinylpyridine ligand by means of comparison with its precursors $\left\{\mathrm{RuCl}_{2}(p \text {-cymene })\right\}_{2}$ and $\mathbf{2 c}$ and with literature data. ${ }^{23}$ a)

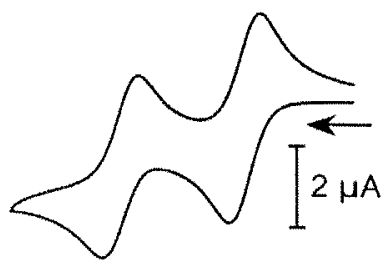

b)

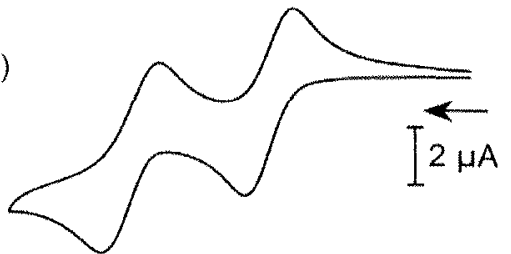

c)
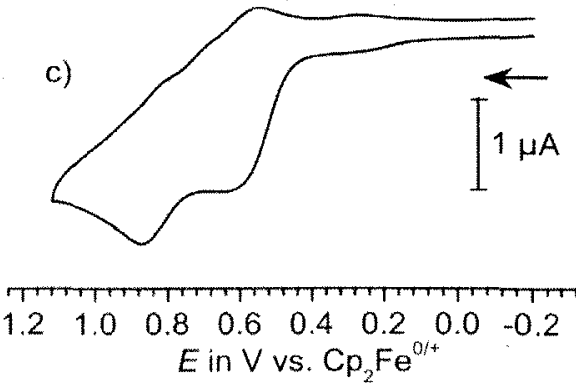

Fig. 6 Cyclic voltammograms of a) $3 a, b) 3 b$ and c) $3 c$ in $\mathrm{CH}_{2} \mathrm{Cl}_{2} / \mathrm{NBu}_{4} \mathrm{PF}_{6}(0.1 \mathrm{M})$ at a sweep rate $v=0.1 \mathrm{~V} \mathrm{~s}^{-1}$.

In their voltammograms each of the complexes $\mathbf{3 a}-\mathbf{c}$ displays two successive one-electron waves in the potential region of 0 to $1 \mathrm{~V}$. While both these waves are chemically reversible for complex $\mathbf{3 a}$, the second one is only partially so for $\mathbf{3 b}$ and even less so for complex $3 \mathrm{c}$ (Fig. 6), indicating that the reactivity of the associated fully oxidized dications increases in the same order. Reversal of the sweep direction after passing through the first oxidation wave indicates full chemical reversibility of the $3 b^{0 /+}$ couple. No reliable value of the reversibility coefficient could, however, be obtained for $3 \mathbf{c}$ owing to the breadths of the individual redox waves and their proximity. Redox potentials as they are compiled in Table 1 reflect, within the usual approximations, the electron densities at each vinyl ruthenium subunit. These themselves are subject to coordination number (five versus six) and, concomitantly, valence electron count (16 versus 18), the electronic nature of the vinyl 


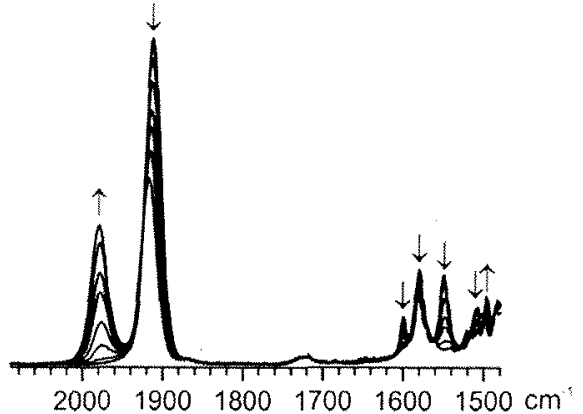

Fig. 7 Spectroscopic changes in the infrared during electrochemical oxidation of complex $3 b$ to $3 b^{+}\left(\mathrm{DCE} / \mathrm{NBu}_{4} \mathrm{PF}_{6}(0.2 \mathrm{M})\right)$ at $\mathrm{r}$ t. $)$.

substituent and to the inductive effect of the benzoate ligand, i.e. to the replacement of the weakly accepting ethynyl moiety by the strongly donating vinyl ruthenium, which is altered into an acceptor when oxidized. Such effects are clearly observable for complexes 3a-c. The sensitivity of the redox potentials to all of these contributions renders an $a$ priori assignment of the order of the redox events ambiguous. Meaningful discussion is thus only possible on the ground of supporting spectroscopic investigations. Useful spectroscopic handles are the shift of $v_{s}(\mathrm{COO})$ of the bridging benzoate ligand and the shift pattern of the $\mathrm{Ru}(\mathrm{CO})$ stretches in IR-spectroscopy, while EPR spectroscopy allows one to identify the primary oxidation site in complexes $3 \mathbf{b}, \mathbf{c}$. The comparatively higher metal character of the $\mathrm{RuCl}_{2}(p$-cymene)(py) or $\mathrm{Ru}\left(\mathrm{CH}=\mathrm{CHCF}_{3}\right)(\mathrm{OOCPh})(\mathrm{CO})\left(\mathrm{P}^{2} \mathrm{Pr}_{3}\right)_{2}$ based radical cations compared to those derived from $\mathrm{RuCl}(\mathrm{CH}=\mathrm{CHPh})(\mathrm{CO})\left(\mathrm{P}^{i} \mathrm{Pr}_{3}\right)_{2}$ renders the former EPR silent at r. t. (c. f. $\mathbf{1 b}, \mathbf{2 b}, \mathbf{c})$ while the latter are EPR active under these conditions $(c, f . \mathbf{1 a}, \mathbf{2 a})$. For the following discussion diruthenium complexes $3 \mathbf{a}-\mathbf{c}$ are schematized as vi-Ru1-bridge-Ru2 or Ru1-bridge-Ru2, respectively, where vi, $\mathrm{Ru} 1$ and $\mathrm{Ru} 2$ represent the terminal vinyl ligand of complexes $\mathbf{3 a}, \mathbf{b}$ and the attached (Ru1) or remote (Ru2) ruthenium atoms and "bridge" stands for the vinylbenzoate or vinylpyridine bridging ligand (Chart 2).

The presence of an EPR signal for $3 \mathbf{b}^{+}$in fluid solution at room temperature (Table 5, Fig. 5) and a sizable shift of $v_{s}(\mathrm{COO})$ during the first oxidation (Table 2, Fig. 7) upon electrolysis at a potential positive of the $3 \mathbf{b}^{0 /+}$ wave let us conclude that the $\mathrm{Ru} 1-$ bridge-Ru 2 unit is oxidized first with chief contributions from the bridge-Ru2 moiety (Table 6). This is further supported by the fact that the lowest energy absorption band of $3 \mathbf{b}^{++}$is found at $9800 \mathrm{~cm}^{-1}(1020 \mathrm{~nm})$ and thus at a considerably lower energy than that of the trifluoropropenyl-based radical cations $1 \mathbf{b}^{\circ}+$ and $2 \mathbf{b}^{\mathbf{}}+$ but at similar positions as in $1 \mathbf{a}^{+}$and $2 \mathbf{a}^{+}$with the same

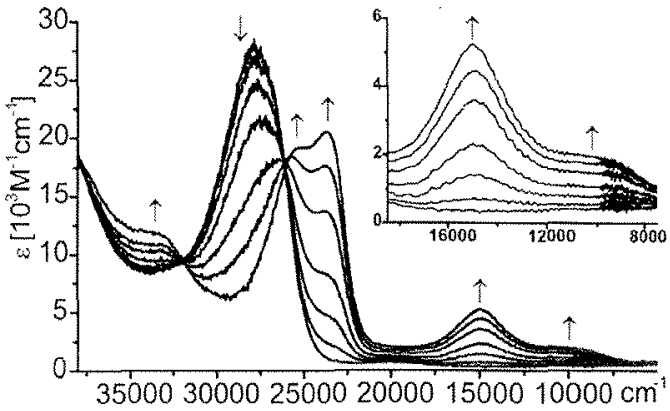

Fig. 8 Spectroscopic changes in the UV/Vis/NIR during electrochemical oxidation of complex $3 \mathbf{b}$ to $3 \mathbf{b}^{+}\left(\mathrm{DCE} / \mathrm{NBu}_{4} \mathrm{PF}_{6}(0.2 \mathrm{M})\right)$ at $\mathrm{r}$. t.; inset: low-energy region magnified.

$\mathrm{Ru}(\mathrm{CH}=\mathrm{CHPh})^{-+}$-type chromophore (Table 3, Fig. 8). Observed shifts of the $\operatorname{Ru}(\mathrm{CO})$ stretches also agree with this hypothesis (Table 2). Under the premise that the half-widths of each of the individual underlying subbands are similar to those found for its mononuclear constituents, the broad band of neutral $3 \mathbf{b}$ deconvolutes into two individual bands positioned at 1914 and $1908 \mathrm{~cm}^{-1}$. Based on their positions in complexes $1 \mathbf{a}$ and $\mathbf{2 b}$ and the expected shifts from replacement of the weakly electron accepting ethynyl function by the electron donating vinyl ruthenium moiety at Rul(OOC-aryl) and of the unsubstituted phenyl ring by the benzoate ruthenium moiety at Ru2, we assign the lower energy band of $\mathbf{3 b}$ to the six-coordinated Rul and the higher energy one to the five-coordinated Ru2 site. Radical cation $3 \mathbf{b}^{\circ}+$ displays a two-band pattern with individual absorptions at 1979 and $1917 \mathrm{~cm}^{-1}$ (see Fig. 7). The above assignment thus means that, upon oxidation, the $\mathrm{Ru} 2-\mathrm{CO}$ band entity undergoes the same $65 \mathrm{~cm}^{-1}$ change as observed for the mononuclear $1 \mathrm{~b} / 1 \mathrm{~b}^{\circ}+$ pair of complexes while the Rul-CO band blue-shifts by $9 \mathrm{~cm}^{-1}$. This indicates that there is only limited transmission of electronic information across the vinyl benzoate bridge. Upon the second oxidation to $3 \mathrm{~b}^{2+}$ a broad CO band at $1989 \mathrm{~cm}^{-1}$ develops (see Fig. S8 of the ESI†). Rapid onset of decomposition during continued electrolysis and our inability to effect complete oxidation render any attempt to meaningful deconvolution of this composite band futile. It is therefore uncertain to what extent the effect of oxidizing the triffuoropropenyl substituted Rul site is felt by the Ru2 one at the other end of the bridge.

The issue of the oxidation-induced $\mathrm{CO}$ band shifts has also been addressed by quantum chemistry. Table 2 summarises calculated $\mathrm{CO}$ stretching frequencies for $\mathrm{PMe}_{3}$ substituted model complex $3 b^{\text {Me }}$. The calculations give two almost degenerate $\mathrm{CO}$ frequencies at 1914 and $1916 \mathrm{~cm}^{-1}$ and two distinct bands at 1959 and $1933 \mathrm{~cm}^{-1}$
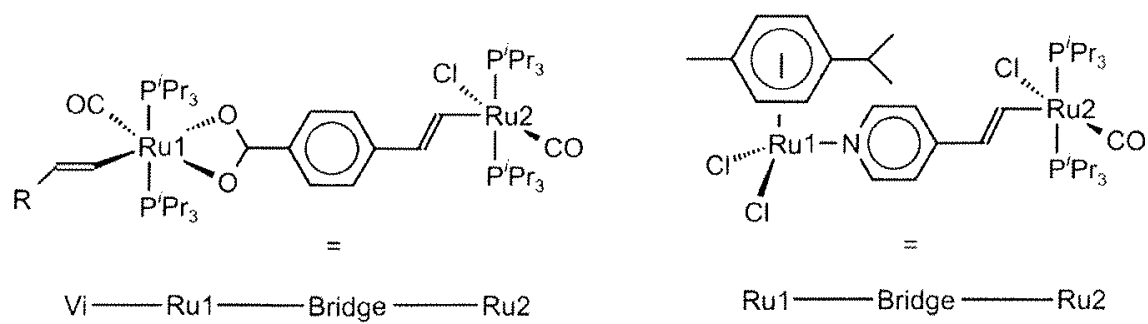

Chart 2 Schematized representation of diruthenium complexes $3 a-c$ 


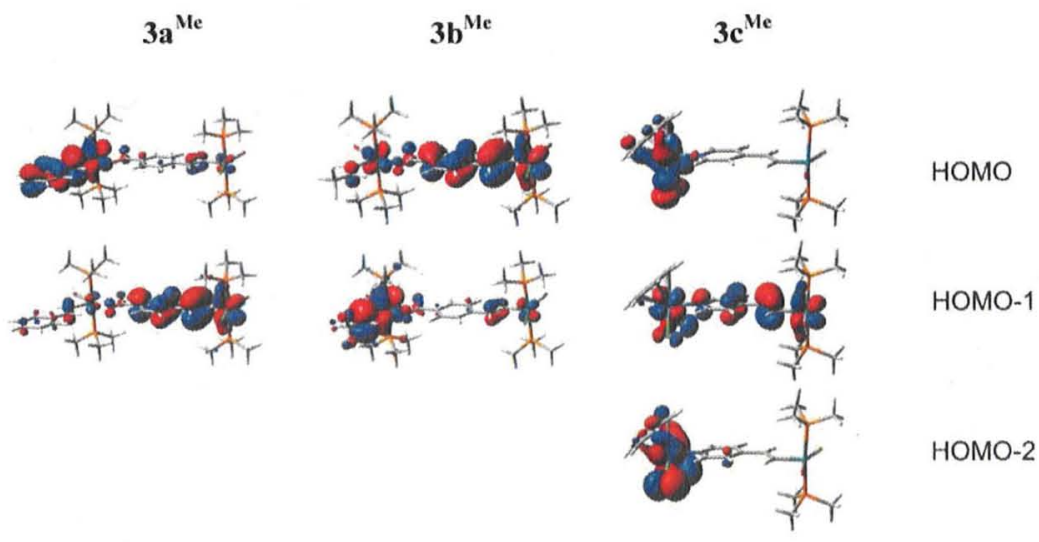

Fig. 9 Contour plots of the highest occupied orbitals of $3 a^{\mathrm{Me}}, \mathbf{3} \mathbf{b}^{\mathrm{Me}}$, and $\mathbf{3} \mathrm{c}^{\mathrm{Me}}$.

for radical cation $3 \mathrm{~b}^{\mathrm{Me}+}$. The splitting of the stretching frequencies is thus underestimated by these calculations. There is hardly any mixing of the individual $\mathrm{CO}$ stretches and the one at the higher energy arises from the five-coordinated Ru2 entity. Calculations on $3 \mathbf{b}^{\mathrm{Me2}+}$ predict individual CO-stretches at 1977 and $1989 \mathrm{~cm}^{-1}$ in agreement with the experimentally observed broad composite band.

For 3a, the assignment of the order of redox events rests on our observation that there is no change of $v_{\mathrm{s}}(\mathrm{OOC})$ of the chelating benzoate ligand upon the first oxidation while the second one leads to a red shift of $12 \mathrm{~cm}^{-1}$ (see Table 2 and Fig. S9 and S10 of the ESI $\dagger$ ). We also note the close resemblance between the $\mathrm{UV} / \mathrm{Vis}$ spectra of $3 \mathrm{a}^{\circ+}$ to those of $2 \mathrm{a}^{\circ+}$ with a prominent lowenergy absorption band at $15015 \mathrm{~cm}^{-1}(666 \mathrm{~nm}$, see Fig. S11 of the ESI + ; c.f. $15060 \mathrm{~cm}^{-1}$ or $664 \mathrm{~nm}$ for $\left.2 \mathrm{a}^{\circ}\right)$. It thus seems that the six-coordinated vi-Rul end group is oxidized prior to the Rulbridge-Ru 2 entity in an inverse order as in $\mathbf{3 b}$. The broad CO band of 3a is resolved into two individual bands at 1914 and $1901 \mathrm{~cm}^{-1}$ when deconvoluted under the above premises. By comparison with 1a and $2 \mathbf{a}$, the band at the lower energy is safely assigned to Ru 1CO. In singly oxidized $3 \mathrm{a}^{\circ}$ this band is shifted to $1973 \mathrm{~cm}^{-1}$ and thus by the same $72 \mathrm{~cm}^{-1}$ as was observed for the $2 \mathrm{a} / 2 \mathrm{a}^{\circ}+$ couple. The first oxidation leaves $v(\mathrm{CO})$ of the Ru2-CO unit essentially unaffected. Fully oxidized $3 \mathrm{a}^{2+}$ exhibits a $\mathrm{CO}$ band at $1978 \mathrm{~cm}^{-1}$ (see Fig. S10 of the ESI $\dagger$ ). Comparison between $3 \mathbf{a}^{\circ+}$ and $3 \mathbf{b}^{\circ+}$ may thus indicate that the vinyl benzoate ligand is even worse at transmitting electronic information when in its reduced, neutral state than when oxidized.

We again traced the development of the IR spectra by quantum chemistry. The CO stretching frequencies calculated at 1908 and $1914 \mathrm{~cm}^{-1}$ for $3 \mathrm{a}^{\mathrm{Me}}$ are shifted to 1925 and $1961 \mathrm{~cm}^{-1}$ for $3 \mathrm{a}^{\mathrm{Mc}+}$ and finally to 1974 and $1983 \mathrm{~cm}^{-1}$ for fully oxidized $3 \mathrm{a}^{\mathrm{Me} 2+}$. Vibrational analysis shows that Rul-CO gives rise to the higher energy stretch of monooxidized $3 \mathbf{a}^{\circ}$. The calculated separation of the two CO-stretches for $3 \mathrm{a}^{\mathrm{Me}^{\circ}+}$ is larger than in the case of $3 \mathbf{b}^{\mathrm{Me}^{\circ}+}$ in agreement with our experimental findings. The larger CO band splitting for monooxidized $3 \mathbf{a}^{\mathrm{Me}^{\circ}+}$ and the lower shift of the remaining reduced subunit with respect to $3 \mathrm{~b}^{\mathrm{Me}}{ }^{\circ}+$ also agree with the calculated spin density distributions with non-negligible contributions from the second ruthenium atom in $\mathbf{3} \mathbf{b}^{\mathrm{Me}} \mathbf{e}^{\mathbf{*}}$ (Fig. S12 of the ESI + ). Calculations on the doubly oxidized species $3 \mathrm{a}^{\mathrm{Mc} 2+}$ and $3 \mathbf{b}^{\mathrm{Mc} 2+}$ indicated that these species have a diradical triplet ground state with spin density almost equally spread over the both vinyl ruthenium subunits (Fig. S15†).

One-electron oxidation of $\mathbf{3 c}$ leads to a moderate shift of the $\mathrm{CO}$ band at the vinylpyridine appended $\left\{\mathrm{RuCl}(\mathrm{CO})\left(\mathrm{P}^{i} \mathrm{Pr}_{3}\right)_{2}\right\}$ unit Ru2 from 1920 to $1932 \mathrm{~cm}^{-1}$ (Fig. S13 of the ESI $\dagger$ ). The rather small magnitude of the $\mathrm{CO}$ band shift and the absence of a detectable EPR signal for monooxidized $3 \mathrm{c}^{\circ}+$ provide further evidence that the first oxidation involves the $\left\{\mathrm{RuCl}_{2}(p\right.$ cymene)(py) $\}$-type site. DFT calculations on $\left(\eta^{6}-\mathrm{C}_{6} \mathrm{H}_{6}\right) \mathrm{Cl}_{2} \mathrm{Ru}(4-$ $\left.\mathrm{NC}_{5} \mathrm{H}_{4}-\mathrm{CH}=\mathrm{CH}\right) \mathrm{RuCl}(\mathrm{CO})\left(\mathrm{PMe}_{3}\right)_{2}\left(3 \mathrm{c}^{\mathrm{Me}}\right)$ confirm the character of the redox orbital (see Table 6) and predict a shift of the Ru2CO band from 1920 to $1940 \mathrm{~cm}^{-1}$ upon oxidation. In further keeping with the $\left\{\mathrm{RuCl}_{2}\right.$ (p-cymene) $\}$ centred oxidation, the electrogenerated radical cation $3 \mathbf{c}^{\circ+}$ also lacks the typical low-energy absorptions of the oxidized styryl ruthenium chromophore (Fig. S14 of the ESI $\dagger$ ). We note, however, that one-electron oxidation under spectroelectrochemical conditions was accompanied by decomposition as follows from the emergence of a higher energy shoulder on the $\mathrm{Ru}(\mathrm{CO})$ band and of a new band at $3330 \mathrm{~cm}^{-1}$ in the IR (see inset in Fig. S13 of the ESI $\dagger$ ). The appearance of an absorption in that region suggests complex dissociation with release of either the $\mathrm{RuCl}(\mathrm{CO})\left(\mathrm{P}^{i} \mathrm{Pr}_{3}\right)_{2}$ moiety and regeneration of the alkyne functionality or breaking of the Ru-pyridine bond and the formation of a pyridinium salt.

Quantum chemical calculations on model complex $3 \mathrm{c}^{\mathrm{Me}}$ agree with a $\left\{\mathrm{RuCl}_{2}\right.$ (p-cymene) $\}$ based HOMO orbital with small contributions from the pyridine $\mathrm{N}$ atom and little delocalization over the vinylpyridine ligand (see Table 6, Fig. 9). On the other hand, the Ru2-CO band shift clearly surpasses that observed for the vinylbenzoate-bridged $3 \mathbf{a} / 3 \mathbf{a}^{{ }^{+}+}$couple where, similar to $3 \mathbf{c} / 3 \mathbf{c}^{\circ}$, the Rul site which connects to the Wernertype donor end of the bridging ligand is oxidized first. This closely resembles the findings for $\mathrm{RuCl}(\mathrm{CO})\left(\mathrm{PPh}_{3}\right)_{2}\left(\mu-\mathrm{NC}_{5} \mathrm{H}_{4}-4-\right.$ $\mathrm{CH}=\mathrm{CH}) \mathrm{RuCl}(\mathrm{CO})\left(\mathrm{P}^{i} \mathrm{Pr}_{3}\right)_{2}$ (3d) with the same general constellation, where oxidation of the $\left\{\mathrm{RuCl}(\mathrm{CO})\left(\mathrm{PPh}_{3}\right)_{2}(\mathrm{py})\right\}$-type endgroup Rul induces a $13 \mathrm{~cm}^{-1}$ blue shift of the $\left\{\mathrm{RuCl}(\mathrm{CO})\left(\mathrm{P}^{i} \operatorname{Pr}_{3}\right)_{2}(4-\right.$ $\left.\left.\mathrm{CH}=\mathrm{CH}-\mathrm{C}_{5} \mathrm{H}_{4} \mathrm{~N}\right)\right\}(=\mathrm{Ru} 2)$ one. ${ }^{3}$

Trends in the observed redox potentials provide some additional experimental measure of the degree of electrostatic/electronic interactions between the bridged Rul and Ru2 sites. For 3a, replacement of the ethynyl benzoate ligand by the $\left(\mathrm{CH}=\mathrm{CHC}_{6} \mathrm{H}_{4} \mathrm{COO}\right) \mathrm{RuCl}(\mathrm{CO})\left(\mathrm{P}^{i} \mathrm{Pr}_{3}\right)_{2}$ moiety decreases the 
oxidation potential of the styryl Rul moiety by $30 \mathrm{mV}$ (compare the first oxidation potentials of compounds $\mathbf{2 a}$ and $3 \mathbf{3}$ ). Likewise, prior oxidation of the vinyl benzoate Ru 2 moiety increases the oxidation potential of the six-coordinated trifluoropropenyl Rul site by $70 \mathrm{mV}$ (compare the first oxidation potential of $\mathbf{2 b}$ to the second one of $3 \mathrm{~b}$ ). Finally, the oxidation potential of the Ru2-vinyl benzoate site changes from 0.34 to $0.43 \mathrm{~V}$ when neutral $\left\{\mathrm{Ru}(\mathrm{CH}=\mathrm{CHCF} 3)(\mathrm{CO})\left(\mathrm{P}^{2} \mathrm{Pr}_{3}\right)_{2}\right\}$ is replaced by oxidized $\left\{\mathrm{Ru}(\mathrm{CH}=\mathrm{CHPh})(\mathrm{CO})\left(\mathrm{P}^{i} \mathrm{Pr}_{3}\right)_{2}\right\}^{*+}$. These effects are rather moderate for the vinylbenzoate-bridged complexes. A much more substantial shift is, however, observed for vinylpyridine-bridged 3c. Thus, the $290 \mathrm{mV}$ displacement of the first, $\left\{\mathrm{RuCl}_{2}\right.$ ( $p$-cymene) $\}$ centred oxidation to a lower potential upon going from $2 \mathrm{c}$ to $3 \mathrm{c}$ is substantially larger than the one of $30 \mathrm{mV}$ observed for the similar ethynyl $\rightarrow \mathrm{RuCl}(\mathrm{CH}=\mathrm{CHR})(\mathrm{CO})\left(\mathrm{P}^{i} \mathrm{Pr}_{3}\right)_{2}$ modification in $2 \mathrm{a} / 3 \mathrm{a}$.

The above assignments of the order of redox events in vinylbenzoate- or vinylpyridine-bridged complexes $3 a-c$ and our conclusions on the viability of charge propagation across the conjugated bridge are supported by quantum chemistry. Our calculations place the HOMO of complexes 3a,c on the carboxylate or imine bonded ruthenium moieties with only small (3a) or negligible (3c) contributions from the bridging vinylbenzoate or vinylpyridine moieties (Fig. 9). The occupied bridge-delocalized frontier molecular orbital is calculated as the HOMO-1, 0.5 (3a) or $0.2(3 \mathbf{c}) \mathrm{eV}$ below the HOMO. For $\mathbf{3 b}$, calculations give the inverse ordering of the occupied FMOs. This latter ordering is, of course, advantageous for achieving fast charge propagation and good hole mobilities along the Ru-bridge-Ru array of a dinuclear complex or the conjugated main chain of a hypothetical $\left[\{\mathrm{Ru}\}-\mathrm{CH}=\mathrm{CH}-\mathrm{C}_{6} \mathrm{H}_{4} \mathrm{COO}-\right]_{\mathrm{n}}$ oligomer at low oxidation (i.e. low doping) levels. The calculations also agree with our experimental observations in predicting that delocalization across the carboxylate group is rather inefficient. This is best traced by comparing the contributions of the vinyl-bonded atom $\mathrm{Ru} 2$ and the carboxylate-bonded atom Rul to the HOMO orbital of $\mathbf{3 b}$ or to the HOMO-1 orbital of $3 a$ (see Table 6). Higher degrees of delocalization are observed for the vinylpyridine-based HOMO-1 orbital of complex $3 \mathbf{c}$

\section{Conclusions}

We have here studied vinylbenzoate- or vinylpyridine-bridged diruthenium divinyl complexes with the aim of elucidating the identity of the primary redox site and the degree of charge and spin delocalization as a function of their overall oxidation state. The observability or non-observability of EPR signals in fluid solution, oxidation-induced $\mathrm{CO}$ and $v_{s}(\mathrm{OOC})$ band shifts, the positions of the Vis or NIR "radical bands" of the respective vinyl ruthenium entities and the redox potentials provide multiple probes which, in concert, allow for an assignment of the order of redox events. Our studies thus show that introducing the trifluoropropenyl ligand at the vinyl-Rul site drives the first oxidation to the bridged Rul$\left(\eta^{2}\right.$-OOC- $\left.\mathrm{C}_{6} \mathrm{H}_{4}-\mathrm{CH}=\mathrm{CH}\right)-\mathrm{Ru} 2$ entity. This contrasts to a first oxidation at the terminal vinyl-Rul subunit in the analogous styryl complex $3 \mathrm{a}$ or the vinylpyridine-bridged complexes $\mathbf{3 c}$ and $\mathbf{3 d}$. Quantum chemical calculations successfully predict the ordering of the HOMO and HOMO-1 levels and provide good qualitative agreements of oxidation-induced $\mathrm{Ru}(\mathrm{CO})$ band shifts and of the Vis/NIR signatures for the oxidized mononuclear precursors with the experiment. They also agree with our experimental observations in that they designate the vinylbenzoate bridge as a poor transmitter which allows for only weak charge and spin delocalization at the radical cation stage. The vinylpyridine linker seems to perform better. It is quite interesting to note that further oxidation of vinylbenzoate-bridged $3 a^{\circ+}$ and $3 b^{\circ}$ to their corresponding dications primarily affects the remaining reduced vinyl ruthenium subunit. Quantum chemical calculations suggest that the dications have a triplet ground state and feature two different oxidized and per se delocalized ruthenium vinyl subunits which are mutually interconnected by a simple carboxylate bridge.

\section{Experimental section}

All preparations were carried out using standard Schlenk techniques. Tetrahydrofuran was distilled over sodium benzophenone ketyl. Dichloromethane was freshly distilled from $\mathrm{CaH}_{2}$ and handled under nitrogen. Other solvents were of reagent grade and were used without prior purification. $\mathrm{RuHCl}(\mathrm{CO})\left(\mathrm{P}^{i} \mathrm{Pr}_{3}\right)_{2}{ }^{24}\{(p-$ cymene) $\left.\mathrm{RuCl}_{2}\right\}_{2}{ }^{25}$ and 4-ethynylbenzoate ${ }^{26}$ were prepared according to literature procedures. 4-Ethynylpyridine was obtained by deprotonation of the commercial hydrochloride salt with $\mathrm{NaHCO}_{3}$. All other chemicals were purchased from Aldrich Chemical Co. The NMR spectra were recorded on a Bruker AV300 spectrometer. Chemical shifts are reported in $\delta(\mathrm{ppm})$ using residual $\mathrm{CHCl}_{3}\left({ }^{\mathrm{t}} \mathrm{H}\right.$ $\delta 7.26 \mathrm{ppm})$ or $\mathrm{CDHCl}_{2}\left({ }^{1} \mathrm{H} \delta 5.32 \mathrm{ppm}\right)$ as the reference. Mass spectra were recorded using EI methods on a Finnigan MAT $710 \mathrm{~A}$ spectrometer. Microanalyses were determined by Analytical Services of the University of Regensburg. UV/Vis spectra were obtained on an Omega 10 spectrometer from Bruins Instruments in HELLMA quartz cuvettes with $1 \mathrm{~cm}$ optical path lengths. The EPR equipment consisted of a Bruker ESP 3000 spectrometer or a Bruker EMX setup equipped with a HP 5350 B frequency counter, a Bruker ER035M gaussmeter and a continuous flow cryostat EPR 900 from Oxford Instruments for low temperature work. Electrochemical work was performed on a BAS CV50 potentiostat in a home-built vacuum tight one-compartment cell using Pt or glassy carbon disk electrodes from BAS as the working electrode, a platinum spiral as the counter electrode and a silver spiral as a pseudo-reference electrode. Each of the spiral-shaped electrodes was welded to Vycon wire and sealed into a glass tube. Counter and reference electrodes are introduced into the cell by appropriate fittings in the side-wall and sealed via a Quickfit screw. The design of the spectroelectrochemical cell follows that of Hartl et al. ${ }^{16} \mathrm{CH}_{2} \mathrm{Cl}_{2}$ and $1,2-\mathrm{C}_{2} \mathrm{H}_{4} \mathrm{Cl}_{2}$ for electrochemical use were of Burdick\&Jackson brand (Fluka) and were distilled from $\mathrm{CaH}_{2}$, deoxygenated by saturation with argon and briefly stored over molecular sieves. Potential calibration was performed by adding ferrocene as an internal standard to the analyte solution. The amount of the reference system was adjusted until its peak currents were comparable to those of the analyte. Potentials are given against the ferrocene/ferrocenium couple. EPR samples were prepared by in situ electrochemical oxidation of the neutral complexes at an appropriate potential. Cautionary Note: 1,2Dichloroethane (DCE) is highly toxic and a suspected carcinogen and should be handled with care. $\mathrm{Tl}^{+}$is highly toxic and has to be handled with appropriate care. 


\section{DFT calculations}

In order to reduce computational time to a reasonable limit, $\mathrm{P}^{i} \mathrm{Pr}_{3}$ ligands were modelled by $\mathrm{PMe}_{3}$ and the cymene ligands by benzene. Quantum chemical studies were performed without any symmetry constraints. The ground state electronic structure was calculated by density functional theory (DFT) methods using the Gaussian $03(09){ }^{27}$ and ADF2009.01 ${ }^{28,29}$ program packages. Electronic transitions were calculated by the time-dependent DFT (TD DFT) method. Open shell systems were calculated by unrestricted Kohn-Sham approach (UKS). For the calculation of IR frequencies, geometry optimization made in vacuo was followed by vibrational analysis. Calculations on doubly oxidized $3 a^{\mathrm{Me} 2+}$ and $3 b^{\mathrm{Mc} 2+}$ resulted in triplet diradical ground sates. Singlet species resulting from double oxidation at just one site were higher in energy. The possibility to have singlet states with antiparallel spins on different parts of complexes was also tested but did not provide convergent solutions.

Within Gaussian calculations the quasirelativistic effective core pseudopotentials and the corresponding optimized set of basis functions for $\mathrm{Ru}^{30}$ and $6-31 \mathrm{G}^{*}$ polarized double- $\zeta$ basis sets ${ }^{31}$ for the remaining atoms were employed. Gaussian calculations employed the hybrid functional Perdew, Burke, Enzerhof ${ }^{32}$ exchange and correlation functional (PBE0). The solvent effect was included in TD DFT by the polarizable conductor calculation model (CPCM) ${ }^{33}$ Within ADF, Slater type orbital (STO) basis sets of triple- $\zeta$ quality with polarization functions were employed with the exception of the $\mathrm{CMe}_{3}$ substituents on $\mathrm{P}$ atoms which were described on a double- $\zeta$ basis. The inner shells were represented by a frozen core approximation, viz. Is for $\mathrm{C}, \mathrm{N}, \mathrm{O}, 1 \mathrm{~s}-2 \mathrm{p}$ for $\mathrm{P}, \mathrm{Cl}$ and $1 \mathrm{~s}-3 \mathrm{~d}$ for $\mathrm{Ru}$ were kept frozen. The calculations were done with the functional including Becke's gradient correction ${ }^{34}$ to the local exchange expression in conjunction with Perdew's gradient correction ${ }^{35}$ to the local correlation (ADF/BP). The scalar relativistic(SR) zero order regular approximation $(\mathrm{ZORA})^{36}$ was used within this study. The g-tensor (calculated by ADF) was obtained from a spin-nonpolarized wave function after incorporating the spin-orbit (SO) coupling by first-order perturbation theory from ZORA Hamiltonian in the presence of a time-independent magnetic field. ${ }^{37,38}$ Electronic transitions and EPR parameters were calculated by single point procedures at optimized structures.

\section{$\mathrm{RuCl}\left(\mathrm{CH}=\mathrm{CH}-\mathrm{CF}_{3}\right)(\mathrm{CO})\left(\mathrm{P}^{i} \mathrm{Pr}_{3}\right)_{2}, 1 \mathrm{~b}$}

$\mathrm{RuClH}(\mathrm{CO})\left(\mathrm{P}^{i} \mathrm{Pr}_{3}\right)_{2}$ (309 $\left.\mathrm{mg}, 0.635 \mathrm{mmol}\right)$ was dissolved in dichloromethane $(10 \mathrm{~mL})$. The solution was treated with $3,3,3-$ trifluoro-1-propyne gas, whereupon the colour changed immediately from orange to deep red. After stirring for $15 \mathrm{~min}$ the solvent was removed to give $1 \mathrm{~b}$ as a red orange solid $(347 \mathrm{mg}, 0.598 \mathrm{mmol}$, 94\%). 'H-NMR (400 MHz, $\mathrm{CD}_{2} \mathrm{Cl}_{2}$ ) $\delta(\mathrm{ppm}): 9.02$ (tqd, ${ }^{3} J_{\mathrm{HH}}=$ $\left.14.1 \mathrm{~Hz},{ }^{4} J_{\mathrm{HF}}=1.9 \mathrm{~Hz},{ }^{3} J_{\mathrm{HP}}=1.0 \mathrm{~Hz}, 1 \mathrm{H}, \mathrm{RuCH}=\mathrm{CH}\right), 5.20$ $\left(\mathrm{tqd},{ }^{3} J_{\mathrm{HH}}=14.1 \mathrm{~Hz},{ }^{3} J_{\mathrm{HF}}=6.2 \mathrm{~Hz},{ }^{4} J_{\mathrm{HP}}=2.2 \mathrm{~Hz}, 1 \mathrm{H}\right.$, $\mathrm{RuCH}=\mathrm{CH}), 2.79-2.69\left(\mathrm{~m}, 6 \mathrm{H}, \mathrm{PC} H \mathrm{CH}_{3}\right), 1.32-1.23(\mathrm{~m}, 36 \mathrm{H}$, PCHCH$\left.{ }_{3}\right) .{ }^{13} \mathrm{C}\left\{{ }^{1} \mathrm{H}\right\}-\mathrm{NMR}\left(400 \mathrm{MHz}, \mathrm{CD}_{2} \mathrm{Cl}_{2}\right): \delta(\mathrm{ppm}): 202.4(\mathrm{t}$, $\left.{ }^{2} J_{\mathrm{CP}}=12.7 \mathrm{~Hz}, C \mathrm{O}\right), 162.4\left(\mathrm{tq},{ }^{3} J_{\mathrm{CF}}=10.5 \mathrm{~Hz},{ }^{2} J_{\mathrm{CP}}=5.3 \mathrm{~Hz}\right.$, $\mathrm{RuCH}=\mathrm{CH}), 121.1\left(\mathrm{tq},{ }^{1} J_{\mathrm{CF}}=269.9 \mathrm{~Hz},{ }^{4} J_{\mathrm{CP}}=1.9 \mathrm{~Hz}, C_{3}\right)$, $120.9\left(\mathrm{tq},{ }^{2} J_{\mathrm{CF}}=31.2 \mathrm{~Hz},{ }^{3} J_{\mathrm{CP}}=3.2 \mathrm{~Hz}, \mathrm{RuCH}=\mathrm{CH}\right), 25.1(\mathrm{vt}$, $\left.{ }^{1} J_{\mathrm{PC}}=10.1 \mathrm{~Hz}, \mathrm{PCHCH}_{3}\right), 20.1$ and $19.8\left(\mathrm{~s}, \mathrm{PCHCH}_{3}\right) .{ }^{31} \mathrm{P}\left\{{ }^{1} \mathrm{H}\right\}-$
NMR (400 MHz, $\left.\mathrm{CD}_{2} \mathrm{Cl}_{2}\right) \delta(\mathrm{ppm}): 39.7\left(\mathrm{q},{ }^{5} J_{\mathrm{PF}}=3.1 \mathrm{~Hz}\right)$. ${ }^{19} \mathrm{~F}\left\{{ }^{\prime} \mathrm{H}\right\}-\mathrm{NMR}\left(400 \mathrm{MHz}, \mathrm{CD}_{2} \mathrm{Cl}_{2}\right) \delta(\mathrm{ppm}):-61.6\left(\mathrm{t},{ }^{5} J_{\mathrm{Fp}}=\right.$ $3.1 \mathrm{~Hz}$ ). Anal. Calc. for $\mathrm{C}_{19} \mathrm{H}_{44} \mathrm{ClF}_{3} \mathrm{P}_{2} \mathrm{Ru}(580.04): \mathrm{C}, 45.55 ; \mathrm{H}$, 7.65. Found: C, $45.02 ; \mathrm{H}, 7.31 \%$.

\section{$\mathrm{Ru}(\mathrm{CH}=\mathrm{CHPh})\left(\mathrm{OOCC}_{6} \mathrm{H}_{4} \mathrm{C} \equiv \mathrm{CH}-4\right)(\mathrm{CO})\left(\mathrm{P}^{i} \mathrm{Pr}_{3}\right)_{2}, 2 \mathrm{a}$}

A solution of $\mathrm{RuCl}(\mathrm{CH}=\mathrm{CHPh})(\mathrm{CO})\left(\mathrm{P}^{i} \mathrm{Pr}_{3}\right)_{2} \quad(156 \mathrm{mg}$, $0.265 \mathrm{mmol})$ in THF $(10 \mathrm{~mL})$ was treated with a suspension of sodium-4-ethynylbenzoate $(66.9 \mathrm{mg}, 0.398 \mathrm{mmol})$ in THF $(25 \mathrm{~mL})$. After stirring for $1 \mathrm{~h}$ the suspension had turned from deep reed into pale yellow. The solvent was removed in vacuo and toluene $(20 \mathrm{~mL})$ was added to the crude product. The suspension was then filtered through Celite. The solvent was evaporated in vacuo and complex 2a was obtained as a yellow solid (150 $\mathrm{mg}, 0.215 \mathrm{mmol}, 81 \%$ ). Alternative procedure: A solution of $\mathrm{RuCl}(\mathrm{CH}=\mathrm{CHPh})(\mathrm{CO})\left(\mathrm{P}^{i} \mathrm{Pr}_{3}\right)_{2}(46.0 \mathrm{mg}, 0.078 \mathrm{mmol})$ in THF $(10 \mathrm{~mL})$ was treated with a suspension of sodium-4ethynylbenzoate $(17.0 \mathrm{mg}, 0.101 \mathrm{mmol})$ in THF $(10 \mathrm{~mL})$ and a suspension of TIPF $_{6}(27.3 \mathrm{mg}, 0.078 \mathrm{mmol})$. After stirring for $10 \mathrm{~min}$ the suspension had turned from deep red into pale yellow and the solvent was then removed in vacuo. The crude product was suspended in dichloromethane $(10 \mathrm{~mL})$ and filtered through Celite. Removal of all volatiles in vacuo left $2 \mathrm{a}$ as yellow solid $(44.7 \mathrm{mg}$, $0.064 \mathrm{mmol}, 83 \%$ ). ${ }^{\mathrm{I}} \mathrm{H}-\mathrm{NMR}\left(600 \mathrm{MHz}, \mathrm{CD}_{2} \mathrm{Cl}_{2}\right.$ ) $\delta$ (ppm): 8.80 $\left(\mathrm{d},{ }^{3} J_{\mathrm{HH}}=15.5 \mathrm{~Hz}, 1 \mathrm{H}, \mathrm{RuCH}=\mathrm{CHPh}\right), 7.96\left(\mathrm{~d}, 2 \mathrm{H},{ }^{3} J_{\mathrm{HH}}=\right.$ $\left.8.2 \mathrm{~Hz}, 2 \mathrm{H}, o-H / \mathrm{OOCC}_{6} H_{4} \mathrm{C} \equiv \mathrm{CH}\right), 7.52\left(\mathrm{~d},{ }^{3} J_{\mathrm{HH}}=8.2 \mathrm{~Hz}\right.$, $\left.2 \mathrm{H}, m-H / \mathrm{OOCC}_{6} H_{4} \mathrm{C} \equiv \mathrm{CH}\right), 7.21-7.12(\mathrm{~m}, 4 \mathrm{H}, o-H$ and $m-$ $H / \mathrm{RuCH}=\mathrm{CH} P h), 6.94\left(\mathrm{t},{ }^{3} J_{\mathrm{HH}}=7.2 \mathrm{~Hz}, p-H / \mathrm{RuCH}=\mathrm{CH} P h\right)$, $6.27\left(\mathrm{~d},{ }^{3} J_{\mathrm{HH}}=15.5 \mathrm{~Hz}, 1 \mathrm{H}, \mathrm{RuCH}=\mathrm{CHPh}\right), 3.25(\mathrm{~s}, 1 \mathrm{H}$, $\left.\mathrm{OOCC}_{6} \mathrm{H}_{4} \mathrm{C} \equiv \mathrm{CH}\right), 2.39-2.31(\mathrm{~m}, 6 \mathrm{H}, \mathrm{PCHCH}), 1.32-1.23(\mathrm{~m}$, $\left.36 \mathrm{H}, \mathrm{PCHCH}_{3}\right) \cdot{ }^{13} \mathrm{C}\left\{{ }^{1} \mathrm{H}\right\}-\mathrm{NMR}\left(600 \mathrm{MHz}, \mathrm{CD}_{2} \mathrm{Cl}_{2}\right): \delta(\mathrm{ppm})$ : $209.2\left(\mathrm{t},{ }^{2} J_{\mathrm{CP}}=14.2 \mathrm{~Hz}, \mathrm{CO}\right), 176.0\left(\mathrm{~s}, \mathrm{OOCC} \mathrm{H}_{4} \mathrm{C} \equiv \mathrm{CH}\right)$, $160.7\left(\mathrm{t},{ }^{2} J_{\mathrm{CP}}=11.5 \mathrm{~Hz}, \mathrm{RuCH}=\mathrm{CHPh}\right), 141.2$ (s, ipso$\mathrm{C} / \mathrm{RuCH}=\mathrm{CH} P h), 134.5\left(\mathrm{~s}\right.$, ipso- $\left.\mathrm{C} / \mathrm{OOCC}_{6} \mathrm{H}_{4} \mathrm{C} \equiv \mathrm{CH}\right), 133.7(\mathrm{t}$, $\left.{ }^{3} J_{\mathrm{CP}}=3.0 \mathrm{~Hz}, \mathrm{RuCH}=\mathrm{CHPh}\right), 132.3\left(\mathrm{~s}, 0-\mathrm{C} / \mathrm{OOCC}{ }_{6} H_{4} \mathrm{C} \equiv \mathrm{CH}\right)$, $129.1\left(\mathrm{~s}, m-\mathrm{C} / \mathrm{OOCC}{ }_{6} H_{4} \mathrm{C}=\mathrm{CH}\right), 128.6(\mathrm{~s}, m-\mathrm{C} / \mathrm{RuCH}=\mathrm{CH} P h)$, $125.4\left(\mathrm{~s}, p-\mathrm{C} / \mathrm{OOCC}_{6} H_{4} \mathrm{C} \equiv \mathrm{CH}\right), 124.1(\mathrm{~s}, o-\mathrm{C} / \mathrm{RuCH}=\mathrm{CH} h)$, $123.6(\mathrm{~s}, p-\mathrm{C} / \mathrm{RuCH}=\mathrm{CH} P h), 83.4\left(\mathrm{~s}, \mathrm{OOCC}_{6} \mathrm{H}_{4} C \equiv \mathrm{CH}\right), 79.5$ (s, $\left.\mathrm{OOCC}_{6} \mathrm{H}_{4} \mathrm{C} \equiv \mathrm{CH}\right), 25.1\left(\mathrm{vt}, J_{\mathrm{PC}}=9.5 \mathrm{~Hz}, \mathrm{PCHCH}_{3}\right), 19.89$ and $19.86\left(\mathrm{~s}, \mathrm{PCHCH}_{3}\right) \cdot{ }^{31} \mathrm{P}\left\{{ }^{1} \mathrm{H}\right\}-\mathrm{NMR}\left(600 \mathrm{MHz}, \mathrm{CD}_{2} \mathrm{Cl}_{2}\right): \delta$ (ppm): 38.39 (s). Anal. Calc. for $\mathrm{C}_{36} \mathrm{H}_{54} \mathrm{O}_{3} \mathrm{P}_{2} \mathrm{Ru}$ (697.82): C, 61.96; H, 7.80. Found: $\mathrm{C}, 61.32 ; \mathrm{H}, 7.57 \%$.

\section{$\mathrm{Ru}\left(\mathrm{CH}=\mathrm{CHCF}_{3}\right)\left(\mathrm{OOCC}_{6} \mathrm{H}_{4} \mathrm{C} \equiv \mathrm{CH}-4\right)(\mathrm{CO})\left(\mathrm{P}^{i} \mathrm{Pr}_{3}\right)_{2}, 2 \mathrm{~b}$}

The synthesis of $\mathbf{2} \mathbf{b}$ was performed analogously to the synthesis of $2 \mathrm{a}$ by treating $\mathrm{RuCl}\left(\mathrm{CH}=\mathrm{CHCF}_{3}\right)(\mathrm{CO})\left(\mathrm{P}^{i} \mathrm{Pr}_{3}\right)_{2}(1 \mathrm{~b}, 259 \mathrm{mg}$, $0.457 \mathrm{mmol})$ in THF $(15 \mathrm{~mL})$ with a suspension of sodium-4ethynylbenzoate (112 $\mathrm{mg}, 0.669 \mathrm{mmol})$ in THF (30 mL). After workup $2 \mathrm{~b}$ was obtained as yellow solid $(276 \mathrm{mg}, 0.401 \mathrm{mmol}$, 90\%). ' $\mathrm{H}-\mathrm{NMR}\left(\mathrm{CD}_{2} \mathrm{Cl}_{2}\right) \delta(\mathrm{ppm}): 9.17\left(\mathrm{tqd},{ }^{3} J_{\mathrm{HH}}=16.0 \mathrm{~Hz}\right.$, $\left.{ }^{4} J_{\mathrm{HF}}=1.9 \mathrm{~Hz},{ }^{3} J_{\mathrm{HP}}=1.31 \mathrm{~Hz}, 1 \mathrm{H}, \mathrm{RuCH}=\mathrm{CHCF}_{3}\right), 7.93(\mathrm{~d}$, $\left.2 \mathrm{H},{ }^{3} J_{\mathrm{HH}}=8.5 \mathrm{~Hz}, 2 \mathrm{H}, 0-H / O O C C_{6} H_{4} \mathrm{C} \equiv \mathrm{CH}\right), 7.51\left(\mathrm{~d},{ }^{3} J_{\mathrm{HH}}=\right.$ $\left.8.5 \mathrm{~Hz}, 2 \mathrm{H}, m-H / \mathrm{OOCC}_{6} H_{4} \mathrm{C} \equiv \mathrm{CH}\right), 5.45\left(\mathrm{tqd},{ }^{3} J_{\mathrm{HH}}=16.0 \mathrm{~Hz}\right.$, $\left.{ }^{3} J_{\mathrm{HF}}=6.3 \mathrm{~Hz},{ }^{4} J_{\mathrm{HP}}=2.0 \mathrm{~Hz}, 1 \mathrm{H}, \mathrm{RuCH}=\mathrm{CHCF} 3\right), 3.25(\mathrm{~s}, 1 \mathrm{H}$, OOCC $\left.{ }_{6} \mathrm{H}_{4} \mathrm{C} \equiv \mathrm{CH}\right), 2.35-2.27\left(\mathrm{~m}, 6 \mathrm{H}, \mathrm{PCHCH}_{3}\right), 1.33-1.20(\mathrm{~m}$, $\left.36 \mathrm{H}, \mathrm{PCHCH} \mathrm{H}_{3}\right) \cdot{ }^{13} \mathrm{C}\left\{{ }^{1} \mathrm{H}\right\}-\mathrm{NMR}\left(600 \mathrm{MHz}, \mathrm{CD}_{2} \mathrm{Cl}_{2}\right) \delta(\mathrm{ppm})$ : $208.5\left(\mathrm{t},{ }^{2} J_{\mathrm{CP}}=13.82 \mathrm{~Hz}, \mathrm{CO}\right), 176.6\left(\mathrm{~s}, \mathrm{OOCC}_{6} \mathrm{H}_{4} \mathrm{C} \equiv \mathrm{CH}\right), 172.4$ 
(qt, $\left.{ }^{3} J_{\mathrm{CF}}=5.3 \mathrm{~Hz},{ }^{2} J_{\mathrm{CP}}=5.5 \mathrm{~Hz}, \mathrm{RuCH}=\mathrm{CHCF}_{3}\right), 134.0(\mathrm{~s}$, ipso$\left.C / \mathrm{OOCC}_{6} \mathrm{H}_{4} \mathrm{C} \equiv \mathrm{CH}\right), 132.3\left(\mathrm{~s}, o-C / \mathrm{OOCC}_{6} H_{4} \mathrm{C} \equiv \mathrm{CH}\right), 129.1$ (s, $\left.m-\mathrm{C} / \mathrm{OOCC}_{6} H_{4} \mathrm{C} \equiv \mathrm{CH}\right), 125.4\left(\mathrm{~s}, p-\mathrm{C} / \mathrm{OOCC}_{6} H_{4} \mathrm{C} \equiv \mathrm{CH}\right), 122.6$ $\left(\mathrm{tq},{ }^{1} J_{\mathrm{CF}}=269.8 \mathrm{~Hz},{ }^{4} J_{\mathrm{CP}}=1.5 \mathrm{~Hz}, \mathrm{RuCH}=\mathrm{CHCF}_{3}\right), 119.7$ (tq, $\left.{ }^{2} J_{\mathrm{CF}}=30.5 \mathrm{~Hz},{ }^{3} J_{\mathrm{CP}}=2.7 \mathrm{~Hz}, \mathrm{RuCH}=\mathrm{CHCF}_{3}\right), 83.4(\mathrm{~s}$, $\left.\mathrm{OOCC}_{6} \mathrm{H}_{4} \mathrm{C} \equiv \mathrm{CH}\right), 79.7\left(\mathrm{~s}, \mathrm{OOCC}_{6} \mathrm{H}_{4} \mathrm{C} \equiv C \mathrm{H}\right), 25.1$ (vt, $J_{\mathrm{PC}}=$ $9.7 \mathrm{~Hz}, \mathrm{PCHCH}_{3}$ ), 19.8 (s(br), $\left.\mathrm{PCHCH}{ }_{3}\right) \mathrm{ppm} .{ }^{31} \mathrm{P}\left\{{ }^{1} \mathrm{H}\right\}-\mathrm{NMR}$ $\left(600 \mathrm{MHz}, \mathrm{CD}_{2} \mathrm{Cl}_{2}\right) \delta(\mathrm{ppm}): 38.9\left(\mathrm{q},{ }^{5} J_{\mathrm{FP}}=2.7 \mathrm{~Hz}\right) \cdot{ }^{19} \mathrm{~F}\left\{{ }^{1} \mathrm{H}\right\}-$ $\operatorname{NMR}\left(600 \mathrm{MHz}, \mathrm{CD}_{2} \mathrm{Cl}_{2}\right): \delta(\mathrm{ppm}):-62.2\left(\mathrm{t},{ }^{5} J_{\mathrm{FP}}=2.7 \mathrm{~Hz}\right)$. Anal. Calc. for $\mathrm{C}_{31} \mathrm{H}_{51} \mathrm{~F}_{3} \mathrm{O}_{3} \mathrm{P}_{2} \mathrm{Ru}(691.74)$ : C, 53.82; H, 7.43. Found: $\mathrm{C}$, $53.69 ; \mathrm{H}, 7.53$.

\section{$\mathrm{RuCl}_{2}\left(p\right.$-cymene) $\left(\mathrm{NC}_{5} \mathrm{H}_{4} \mathrm{C} \equiv \mathrm{CH}\right), 2 \mathrm{c}$}

A suspension of $\left[\mathrm{RuCl}_{2} \text { (p-cymene) }\right]_{2}(500 \mathrm{mg}, 0.816 \mathrm{mmol}, 1 \mathrm{eq})$ in $12 \mathrm{~mL}$ THF was treated with a solution of 4-ethynylpyridine (205 $\mathrm{mg}, 1.99 \mathrm{mmol}, 2.4 \mathrm{eq}$ ) in $2 \mathrm{~mL}$ THF. The dark orange suspension was stirred for $5 \mathrm{~d}$ whereupon the colour changed to light brown. All volatiles were then removed and $2 \mathrm{c}$ was obtained as a yellow brown, microcrystalline product after washing with ether and hexanes (614 $\mathrm{mg}, 1.50 \mathrm{mmol} 92 \%$ ). 'H-NMR (300 MHz, $\left.\mathrm{CDCl}_{3}\right) \delta(\mathrm{ppm}): 9.02\left(\mathrm{~d}, 2 \mathrm{H},{ }^{3} J_{\mathrm{HH}}=\right.$ $\left.6.70 \mathrm{~Hz}, o-H / N C_{5} H_{4} \mathrm{C} \equiv \mathrm{CH}\right), 7.44\left(\mathrm{~d}, 2 \mathrm{H},{ }^{3} J_{\mathrm{HH}}=6.70 \mathrm{~Hz}, m-\right.$ $\left.H / N C_{5} H_{4} \mathrm{C} \equiv \mathrm{CH}\right), 5.45\left(\mathrm{~d}, 2 \mathrm{H},{ }^{3} J_{\mathrm{HH}}=6.03 \mathrm{~Hz}, o-H / p\right.$-cymene), $5.22\left(\mathrm{~d}, 2 \mathrm{H},{ }^{3} J_{\mathrm{HH}}=6.03 \mathrm{~Hz}, m-H / p\right.$-cymene $), 3.45(\mathrm{~s}, 1 \mathrm{H}$, $\left.\mathrm{NC}_{5} \mathrm{H}_{4} \mathrm{C} \equiv \mathrm{CH}\right)$ ), 3.00 (sept, $1 \mathrm{H},{ }^{3} J_{\mathrm{HH}}=6.93 \mathrm{~Hz}, \mathrm{CH}\left(\mathrm{CH}_{3}\right)_{2} / p$ cymene), 2.11 (s, $3 \mathrm{H}, \mathrm{CH}_{3} / p$-cymene), $1.31\left(\mathrm{~d}, 6 \mathrm{H},{ }^{3} \mathrm{~J}_{\mathrm{HH}}=6.93 \mathrm{~Hz}\right.$, $\mathrm{CH}\left(\mathrm{CH}_{3}\right)_{2} / p$-cymene). Anal. Calc. for $\mathrm{C}_{17} \mathrm{H}_{19} \mathrm{Cl}_{2} \mathrm{NRu}$ (409.31): $\mathrm{C}$, $49.88 ; \mathrm{H}, 4.68 ; \mathrm{N}, 3.42$. Found: C, 49.43; H, 4.95; N, 3.10\%.

\section{$\left\{(\mathrm{CO})\left(\mathrm{P}^{i} \mathrm{Pr}_{3}\right)_{2}(\mathrm{CO})(\mathrm{PhCH}=\mathrm{CH}) \mathrm{Ru}\right\}\left(\mu-\mathrm{OOCC}_{6} \mathrm{H}_{4} \mathrm{CH}=\mathrm{CH}\right)-$ $\left\{\mathrm{RuCl}(\mathrm{CO})\left(\mathrm{P}^{i} \mathrm{Pr}_{3}\right)_{2}\right\}, 3 \mathrm{a}$}

To a solution of $2 \mathrm{a}(78 \mathrm{mg}, 0.112 \mathrm{mmol})$ in $\mathrm{CH}_{2} \mathrm{Cl}_{2}(6 \mathrm{~mL})$ was added a solution of $\mathrm{RuClH}(\mathrm{CO})\left(\mathrm{P}^{\mathrm{i}} \mathrm{Pr}_{3}\right)_{2}(55 \mathrm{mg}, 0.112 \mathrm{mmol})$ in $\mathrm{CH}_{2} \mathrm{Cl}_{2}(7 \mathrm{~mL})$. The mixture rapidly turned from yellow to deep red. After stirring for $30 \mathrm{~min}$ the solvent was removed in vacuo to give 3a as a deep red solid (127 $\mathrm{mg}$, $0.107 \mathrm{mmol}, 96 \%)$. 'H-NMR (600 $\left.\mathrm{MHz}, \mathrm{CD}_{2} \mathrm{Cl}_{2}\right) \delta$ (ppm): $8.91\left(\mathrm{~d},{ }^{3} J_{\mathrm{HH}}=13.38 \mathrm{~Hz}, 1 \mathrm{H}, \mathrm{OOCC}_{6} \mathrm{H}_{4} \mathrm{CH}=\mathrm{CHRu}\right), 8.83$ $\left(\mathrm{d}, 1 \mathrm{H},{ }^{3} J_{\mathrm{HH}}=15.50 \mathrm{~Hz}, \mathrm{RuCH}=\mathrm{CHPh}\right), 7.76\left(\mathrm{~d}, 2 \mathrm{H},{ }^{3} J_{\mathrm{HH}}=\right.$ $\left.8.20 \mathrm{~Hz}, \quad 0-H / \mathrm{OOCC}_{6} H_{4} \mathrm{CH}=\mathrm{CHRu}\right), 7.21-7.20(\mathrm{~m}, 4 \mathrm{H}, 0-$ $H$ and $m-H / \mathrm{RuCH}=\mathrm{CH} P h), 7.01\left(\mathrm{~d}, 2 \mathrm{H},{ }^{3} J_{H H}=8.20 \mathrm{~Hz}\right.$, $\left.m-H / O O C C_{6} H_{4} \mathrm{CH}=\mathrm{CHRu}\right), 6.92\left(\mathrm{t}, 1 \mathrm{H},{ }^{3} J_{\mathrm{HH}}=7.14 \mathrm{~Hz}, p-\right.$ $H / \mathrm{RuCH}=\mathrm{CH} P h), 6.26\left(\mathrm{~d},{ }^{3} J_{\mathrm{HH}}=15.50 \mathrm{~Hz}, 1 \mathrm{H}, \mathrm{RuCH}=\mathrm{C} H \mathrm{Ph}\right)$, $6.08\left(\mathrm{~d},{ }^{3} J_{\mathrm{HH}}=13.38 \mathrm{~Hz}, \quad 1 \mathrm{H}, \quad \mathrm{OOCC}_{6} \mathrm{H}_{4} \mathrm{CH}=\mathrm{CHRu}\right)$, $2.76\left(\mathrm{~m}, 6 \mathrm{H}, \quad \mathrm{PCHCH} \mathrm{CH}_{3} / \mathrm{RuCH}=\mathrm{CHC}_{6} \mathrm{H}_{4} \mathrm{COO}\right), 2.35(\mathrm{~m}$, $\left.6 \mathrm{H}, \quad \mathrm{PCHCH}_{3} / \mathrm{RuOOCC}_{6} \mathrm{H}_{4} \mathrm{CH}=\mathrm{CH}\right), \quad 1.34-1.23 \quad(\mathrm{~m}, \quad 72$ $\left.\mathrm{H}, \quad \mathrm{PCHCH} H_{3}\right) .{ }^{13} \mathrm{C}\left\{{ }^{1} \mathrm{H}\right\}-\mathrm{NMR} \quad\left(600 \mathrm{MHz}, \quad \mathrm{CD}_{2} \mathrm{Cl}_{2}\right) \quad \delta$ (ppm): $209.4 \quad\left(\mathrm{~s}, \quad \mathrm{CO} / \mathrm{RuCH}=\mathrm{CHC}_{6} \mathrm{H}_{4} \mathrm{COO}\right), 203.1 \quad(\mathrm{~s}$, $\left.\mathrm{CO} / \mathrm{RuOOCC}_{6} \mathrm{H}_{4} \mathrm{CH}=\mathrm{CH}\right), 177.5\left(\mathrm{~s}, \mathrm{OOCC}_{6} \mathrm{H}_{4} \mathrm{CH}=\mathrm{CHRu}\right)$, $161.5\left(\mathrm{t},{ }^{2} J_{\mathrm{CP}}=11.2 \mathrm{~Hz}, \quad \mathrm{RuCH}=\mathrm{CHPh}\right), 156.5(\mathrm{t}$, $\left.{ }^{2} J_{\mathrm{CP}}=11.1 \mathrm{~Hz}, \quad \mathrm{OOCC}_{6} \mathrm{H}_{4} \mathrm{CH}=\mathrm{CHRu}\right), \quad 141.56 \quad(\mathrm{~s}, \quad p-$ $\left.\mathrm{C} / \mathrm{OOCC}_{6} H_{4} \mathrm{CH}=\mathrm{CHRu}\right), 141.32$ (s, ipso- $\left.\mathrm{C} / \mathrm{RuCH}=\mathrm{CH} P h\right)$, $134.4\left(\mathrm{~s}, \quad \mathrm{OOCC}_{6} \mathrm{H}_{4} \mathrm{CH}=\mathrm{CHRu}\right), 133.6 \quad(\mathrm{~s}, \quad \mathrm{RuCH}=\mathrm{CHPh})$, 129.7 (s, ipso- $\mathrm{C} / \mathrm{OOCC}_{6} \mathrm{H}_{4} \mathrm{CH}=\mathrm{CHRu}$ ), 129.4 (s, o$\left.C / \mathrm{OOC} C_{6} H_{4} \mathrm{CH}=\mathrm{CHRu}\right), 128.6(\mathrm{~s}, m-\mathrm{C} / \mathrm{RuCH}=\mathrm{CH} P h), 124.1$ (s, o- $\mathrm{C} / \mathrm{RuCH}=\mathrm{CH} P h), 123.6\left(\mathrm{~s}, m-\mathrm{C} / \mathrm{OOC} C_{6} H_{4} \mathrm{CH}=\mathrm{CHRu}\right)$, $123.4(s, p-C / \mathrm{RuCH}=\mathrm{CH} P h), 25.2\left(\mathrm{vt}, \quad J_{\mathrm{PC}}=9.3 \mathrm{~Hz}\right.$,
$\mathrm{PCHCH}_{3} / \mathrm{RuOOCC}_{6} \mathrm{H}_{4} \mathrm{CH}=\mathrm{CH}$ ), 24.9 (vt, $J_{\mathrm{PC}}=9.9 \mathrm{~Hz}$, $\left.\mathrm{PCHCH}_{3} / \mathrm{RuCH}=\mathrm{CHC}_{6} \mathrm{H}_{4} \mathrm{COO}\right), 20.2-19.8(\mathrm{~m}, \mathrm{PCHCH}$ ). ${ }^{31} \mathrm{P}\left\{{ }^{\prime} \mathrm{H}\right\}-\mathrm{NMR} \quad\left(600 \mathrm{MHz}, \quad \mathrm{CD}_{2} \mathrm{Cl}_{2}\right) \quad \delta \quad(\mathrm{ppm}) ; 39.1 \quad(\mathrm{~s}$, $\mathrm{P} / \mathrm{RuCH}=\mathrm{CHC}_{6} \mathrm{H}_{4} \mathrm{COO}$ ), 38.7 (s, P/RuOOCC $\left.6 \mathrm{H}_{4} \mathrm{CH}=\mathrm{CH}\right)$. Anal. Calc. for $\mathrm{C}_{55} \mathrm{H}_{97} \mathrm{ClO}_{4} \mathrm{P}_{4} \mathrm{Ru}_{2}$ (1183.84): C, 55.80; H, 8.26. Found: C, 55.32; H, 7.99.

\section{$\left\{\left(\mathrm{P}^{i} \mathrm{Pr}_{3}\right)_{2}(\mathrm{CO})\left(\mathrm{CH}=\mathrm{CHCF}_{3}\right)(\mathrm{Ru}\}\left(\mu-\mathrm{OOCC}_{6} \mathrm{H}_{4} \mathrm{CH}=\mathrm{CH}\right)-\right.$ $\left\{\mathrm{RuCl}(\mathrm{CO})\left(\mathrm{P}^{i} \mathrm{Pr}_{3}\right)_{2}\right\} \mathbf{3 b}$}

In analogy to the synthesis of $3 \mathrm{a}$ a solution of $\mathrm{RuClH}(\mathrm{CO})\left(\mathrm{P}^{i} \mathrm{Pr}_{3}\right)_{2}$ $(62.5 \mathrm{mg}, 0.129 \mathrm{mmol})$ in $\mathrm{CH}_{2} \mathrm{Cl}_{2}(10 \mathrm{~mL})$ was added to $2 \mathrm{~b}(89 \mathrm{mg}$, $0.129 \mathrm{mmol}$ ) dissolved in $\mathrm{CH}_{2} \mathrm{Cl}_{2}(5 \mathrm{~mL})$. After stirring for $30 \mathrm{~min}$ the red solution was evaporated to dryness to give $\mathbf{3 b}$ as a red solid (144 mg, $0.122 \mathrm{mmol}, 95 \%)$. ${ }^{1} \mathrm{H}-\mathrm{NMR}\left(600 \mathrm{MHz}, \mathrm{CD}_{2} \mathrm{Cl}_{2}\right.$ ) $\delta(\mathrm{ppm}): 9.19\left(\mathrm{~d}(\mathrm{br}),{ }^{3} J_{\mathrm{HH}}=15.96 \mathrm{~Hz}, 1 \mathrm{H}, \mathrm{RuC} H=\mathrm{CHCF}_{3}\right), 8.93$ $\left(\mathrm{d},{ }^{3} J_{\mathrm{HH}}=13.35 \mathrm{~Hz}, 1 \mathrm{H}, \mathrm{OOCC}_{6} \mathrm{H}_{4} \mathrm{CH}=\mathrm{CHRu}\right), 7.73(\mathrm{~d}, 2 \mathrm{H}$, $\left.{ }^{3} J_{\mathrm{HH}}=7.95 \mathrm{~Hz}, 0-H / \mathrm{OOCC}_{6} H_{4} \mathrm{CH}=\mathrm{CHRu}\right), 7.00\left(\mathrm{~d}, 2 \mathrm{H},{ }^{3} J_{\mathrm{HH}}=\right.$ $\left.7.95 \mathrm{~Hz}, m-H / \mathrm{OOCC}_{6} H_{4} \mathrm{CH}=\mathrm{CHRu}\right), 6.07\left(\mathrm{~d},{ }^{3} J_{\mathrm{HH}}=13.35 \mathrm{~Hz}\right.$, $\left.1 \mathrm{H}, \mathrm{OOCC}_{6} \mathrm{H}_{4} \mathrm{CH}=\mathrm{CHRu}\right), 5.40\left(\mathrm{~m}, 1 \mathrm{H}, \mathrm{RuCH}=\mathrm{C} H \mathrm{CF}_{3}\right)$, $2.75\left(\mathrm{~m}, 6 \mathrm{H}, \quad \mathrm{PCHCH} 3 / \mathrm{RuCH}=\mathrm{CHC}_{6} \mathrm{H}_{4} \mathrm{COO}\right), 2.34(\mathrm{~m}$, $\left.6 \mathrm{H}, \mathrm{PCHCH} / \mathrm{RuOOCC}_{6} \mathrm{H}_{4} \mathrm{CH}=\mathrm{CH}\right), 1.34-1.20(\mathrm{~m}, 72 \mathrm{H}$, $\left.\mathrm{PCHCH}_{3}\right),{ }^{13} \mathrm{C}\left\{{ }^{\prime} \mathrm{H}\right\}-\mathrm{NMR}\left(600 \mathrm{MHz}, \mathrm{CD}_{2} \mathrm{Cl}_{2}\right) \delta$ (ppm): $208.7\left(\mathrm{t},{ }^{2} J_{\mathrm{CP}}=13.94 \mathrm{~Hz}, \quad \mathrm{CO} / \mathrm{RuCH}=\mathrm{CHC}_{6} \mathrm{H}_{4} \mathrm{COO}\right)$, $203.1\left(\mathrm{t},{ }^{2} J_{\mathrm{CP}}=12.84 \mathrm{~Hz}, \quad \mathrm{CO} / \mathrm{RuOOCC}_{6} \mathrm{H}_{4} \mathrm{CH}=\mathrm{CH}\right)$, $178.1\left(\mathrm{~s}, \mathrm{OOCC}_{6} \mathrm{H}_{4} \mathrm{CH}=\mathrm{CHRu}\right), 173.2\left(\mathrm{~m}, \mathrm{RuCH}=\mathrm{CHCF}_{3}\right)$, $157.0\left(\mathrm{t},{ }^{2} J_{\mathrm{CP}}=10.64 \mathrm{~Hz}, \quad \mathrm{OOCC}_{6} \mathrm{H}_{4} \mathrm{CH}=\mathrm{CHRu}\right), \quad 141.9$ (s, $p$ - $\left.\mathrm{C} / \mathrm{OOCC}_{6} \mathrm{H}_{4} \mathrm{CH}=\mathrm{CHRu}\right), \quad 134.3$ (s, $\quad \mathrm{OOCC}_{6} \mathrm{H}_{4} \mathrm{CH}=$ $\mathrm{CHRu}), \quad 129.4 \quad\left(\mathrm{~s}, \quad o-\mathrm{C} / \mathrm{OOCC}_{6} H_{4} \mathrm{CH}=\mathrm{CHRu}\right), \quad 129.3$ (s, ipso- $\left.\mathrm{C} / \mathrm{OOCC}{ }_{6} H_{4} \mathrm{CH}=\mathrm{CHRu}\right), \quad 123.6 \quad$ (s, m- $\mathrm{C} / \mathrm{OO}-$ $\left.\mathrm{CC}_{6} H_{4} \mathrm{CH}=\mathrm{CHRu}\right), 122.7\left(\mathrm{q},{ }^{\mathrm{I}} J_{\mathrm{CF}}=269.2, \mathrm{RuCH}=\mathrm{CHCF}_{3}\right)$, $119.5\left(\mathrm{q},{ }^{2} J_{\mathrm{CF}}=30.1, \quad \mathrm{RuCH}=C \mathrm{HCF}_{3}\right), 25.1\left(\mathrm{vt}, J_{\mathrm{PC}}=\right.$ $9.5 \mathrm{~Hz}, \quad \mathrm{PCHCH}_{3} / \mathrm{RuOOCC}_{6} \mathrm{H}_{4} \mathrm{CH}=\mathrm{CH}$ ), 24.9 (vt, $J_{\mathrm{PC}}=$ $\left.9.9 \mathrm{~Hz}, \quad \mathrm{PCHCH} / \mathrm{RuCH}=\mathrm{CHC}_{6} \mathrm{H}_{4} \mathrm{COO}\right), 20.2-19.7 \quad(\mathrm{~m}$, $\left.\mathrm{PCHCH}_{3}\right) .{ }^{31} \mathrm{P}\left\{{ }^{1} \mathrm{H}\right\}-\mathrm{NMR} \quad\left(600 \mathrm{MHz}, \mathrm{CD}_{2} \mathrm{Cl}_{2}\right) \quad \delta$ (ppm): $39.4\left(\mathrm{q},{ }^{5} J_{\mathrm{FP}}=2.80 \mathrm{~Hz}, \mathrm{P} / \mathrm{RuOOCC}_{6} \mathrm{H}_{4} \mathrm{CH}=\mathrm{CH}\right), 39.1$ (s, $\left.\mathrm{P} / \mathrm{RuCH}=\mathrm{CHC}_{6} \mathrm{H}_{4} \mathrm{COO}\right) .{ }^{19} \mathrm{~F}-\mathrm{NMR} \quad\left(600 \mathrm{MHz}, \quad \mathrm{CD}_{2} \mathrm{Cl}_{2}\right)$ : $\delta(\mathrm{ppm}):-61.6\left(\mathrm{t},{ }^{5} J_{\mathrm{FP}}=2.80 \mathrm{~Hz}\right)$. Anal. Calc. for $\mathrm{C}_{50} \mathrm{H}_{92} \mathrm{ClF}_{3} \mathrm{O}_{4} \mathrm{P}_{4} \mathrm{Ru}_{2}$ (1175.74): C, 51.08; H, 7.89. Found: $\mathrm{C}$, 49.85; H, 7.95:

\section{$\left\{(p\right.$-cymene $\left.) \mathrm{Cl}_{2} \mathrm{Ru}\right\}\left(\mu-\mathrm{NC}_{5} \mathrm{H}_{4} \mathrm{CH}=\mathrm{CH}\right)\left\{\mathrm{RuCl}(\mathrm{CO})\left(\mathrm{P}^{i} \mathrm{Pr}_{3}\right)_{2}\right\}, 3 \mathrm{c}$}

A suspension of $\mathrm{RuCl}_{2}$ (p-cymene)(4- $\left.\mathrm{NC}_{5} \mathrm{H}_{4} \mathrm{CCH}\right) 2 \mathrm{c}(77.7 \mathrm{mg}$, $0.190 \mathrm{mmol})$ in $15 \mathrm{~mL}$ of $\mathrm{CH}_{2} \mathrm{Cl}_{2}$ was treated with a solution of $\mathrm{RuClH}(\mathrm{CO})\left(\mathrm{P}^{i} \mathrm{Pr}_{3}\right)_{2}(92 \mathrm{mg}, 0.190 \mathrm{mmol})$ in $8 \mathrm{~mL}$ of $\mathrm{CH}_{2} \mathrm{Cl}_{2}$. The red solution was stirred for $30 \mathrm{~min}$. After removal of all volatiles in vacuo the product was obtained as a red solid (160 mg, $0.179 \mathrm{mmol}, 94 \%$ ). 'H-NMR (400 MHz, $\mathrm{CDCl}_{3}$ ) $\delta$ (ppm): $9.73\left(\mathrm{~d}, 1 \mathrm{H},{ }^{3} J_{\mathrm{HH}}=13.64 \mathrm{~Hz}, \mathrm{NC}_{5} \mathrm{H}_{4} \mathrm{CH}=\mathrm{CHRu}\right), 8.56$ $\left(\mathrm{d}, 2 \mathrm{H},{ }^{3} J_{\mathrm{HH}}=6.80 \mathrm{~Hz}, o-H / N C_{5} H_{4} \mathrm{CH}=\mathrm{CHRu}\right), 6.78(\mathrm{~d}$, $\left.2 \mathrm{H},{ }^{3} J_{\mathrm{HH}}=6.80 \mathrm{~Hz}, m-H / N C_{5} H_{4} \mathrm{CH}=\mathrm{CHRu}\right), 6.05(\mathrm{~d}, 1 \mathrm{H}$, $\left.{ }^{3} J_{\mathrm{HH}}=13.64 \mathrm{~Hz}, \mathrm{NC}_{5} \mathrm{H}_{4} \mathrm{CH}=\mathrm{CHRu}\right), 5.36\left(\mathrm{~d}, 2 \mathrm{H},{ }^{3} J_{\mathrm{HH}}=\right.$ $6.00 \mathrm{~Hz}, m-H / p$-cymene $), 5.18\left(\mathrm{~d}, 2 \mathrm{H},{ }^{3} J_{\mathrm{HH}}=6.00 \mathrm{~Hz}, o-\right.$ $H / p$-cymene), 3.00 (sept, $1 \mathrm{H},{ }^{3} J_{\mathrm{HH}}=6.90 \mathrm{~Hz}, \mathrm{CH}\left(\mathrm{CH}_{3}\right)_{2} / p$ cymene), 2.78-2.66 (m, $6 \mathrm{H}, \mathrm{PCHCH} 3), 2.11\left(\mathrm{~s}, \mathrm{CH}_{3} / p\right.$-cymene), $1.30-1.19\left(\mathrm{~m}, 42 \mathrm{H}, \mathrm{CH}\left(\mathrm{CH}_{3}\right)_{2} / p\right.$-cymene, $\left.\mathrm{PCHCH}_{3}\right) .{ }^{13} \mathrm{C}\left\{{ }^{1} \mathrm{H}\right\}-$ NMR (400 MHz, $\left.\mathrm{CDCl}_{3}\right) \delta(\mathrm{ppm}): 202.0(\mathrm{~s}, \mathrm{CO}), 170.3$ (s, $\left.\mathrm{NC}_{5} \mathrm{H}_{4} \mathrm{CH}=\mathrm{CHRu}\right), 153.8\left(\mathrm{~s}, o-\mathrm{C} / \mathrm{NC}_{5} \mathrm{H}_{4} \mathrm{CH}=\mathrm{CHRu}\right), 144.6(\mathrm{~s}$, 
$\left.p-\mathrm{C} / N C_{5} H_{4} \mathrm{CH}=\mathrm{CHRu}\right), 130.9\left(\mathrm{~s}, \mathrm{NC}_{5} \mathrm{H}_{4} \mathrm{CH}=\mathrm{CHRu}\right), 118.7(\mathrm{~s}$, $m-C / N C_{5} H_{4} \mathrm{CH}=\mathrm{CHRu}$ ), 103.5 (s, $p$-C/p-cymene), 96.5 (s, ipso$C / p$-cymene), 82.5 (s, o-C/p-cymene), 82.1 (s, $m$ - $C / p$-cymene), $30.5\left(\mathrm{~s}, \mathrm{CH}\left(\mathrm{CH}_{3}\right)_{2} / p\right.$-cymene) $), 24.6\left(\mathrm{vt}, J_{\mathrm{PC}}=10.0 \mathrm{~Hz}, \mathrm{PCHCH}_{3}\right.$ ), 22.2 (s, $\mathrm{CH}\left(\mathrm{CH}_{3}\right)_{2} / p$-cymene)), 19.9 and 19.5 (s, $\left.\mathrm{PCHCH}_{3}\right), 18.1$ (s, $\mathrm{CH}_{3} / p$-cymene). ${ }^{31} \mathrm{P}\left\{{ }^{1} \mathrm{H}\right\}$-NMR ( $400 \mathrm{MHz}, \mathrm{CD}_{2} \mathrm{Cl}_{2}$ ) $\delta$ (ppm); 39.9 (s). Anal. Calc. for $\mathrm{H}_{6} \mathrm{C}_{36} \mathrm{Cl}_{3} \mathrm{NO}_{2} \mathrm{P}_{2} \mathrm{Ru}_{2}$ (895.32): $\mathrm{C} 48.29 ; \mathrm{H}$, $7.00 ; \mathrm{N}, 1.56$. Found: $\mathrm{C}, 47.76 ; \mathrm{H}, 6.36 ; \mathrm{N}, 1.48 \%$.

\section{Acknowledgements}

Financial support of this work by Deutsche Forschungsgemeinschaft (DFG Wi1272/7-2) is gratefully acknowledged. The Grant Agency of the Academy of Sciences of the Czech Republic (KAN100400702) and the Ministry of Education of the Czech Republic (Grant COST IP05OC68) are acknowledged by S. Z. We also thank the referees for their helpful comments.

\section{References}

1 J. Maurer, R. F. Winter, B. Sarkar, J. Fiedler and S. Záliš, Chem. Commun., 2004, 1900-1901.

2 J. Maurer, M. Linseis, B. Sarkar, B. Schwerderski, M. Niemeyer, W. Kaim, S. Záliš, C. Anson, M. Zabel and R. F. Winter, J. Am. Chem. Soc., 2008, 130, 259-268.

3 J. Maurer, B. Sarkar, W. Kaim, R. F. Winter and S. Záliš, Chem.-Eur: J, $2007,13,10257-10272$.

4 J. Maurer, B. Sarkar, B. Schwederski, W. Kaim, R. F. Winter and S. Záliš, Organometallics, 2006, 25, 3701-3712

5 M. Pichimaier, R. F. Winter, M. Zabel and S. Záliş, J. Am. Chem. Soc, $2009,131,4892-4903$

6 A. F. Hill, ed. D. E. Shriver and M. I. Bruce, Pergamon, Oxford, Editon edn, 1995, vol. 7, pp. 399-411.

7 H. Werner, M. A. Esteruelas and H. Otto, Organometallics, 1986, 5, 2295.

8 H. Werner, U. Meyer, K. Peters and H. G. von Schnering, Chem. Ber, 1989, 122, 2089-2107.

9 S. Jung, C. D. Brandt, J. Wolf and H. Werner, Dalton Trans., 2004, 375-383.

10 S. S. Deshpande, S. Gopinathan and C. Gopinathan, J. Organomet. Chem., 1991, 415, 265-270.

11 C. J. Pickett and D. Pletcher, J. Organomet. Chem., 1975, 102, 327-333.

12 J. Chatt, C. T. Kan, G. J. Leigh, C. J. Pickett and D. R. Stanley, J. Chem. Soc., Dalton Trants, 1980, 2032-2038.

13 A. B. P. Lever, Inorg. Chem., 1990, 29, 1271-1285.

14 A. J. L. Pombiero, Inorg. Chim. Acta, 1985, 103, 95-103.

15 D. R. Robertson, T. A. Stephenson and T. Arthur, J. Organomet. Chem., $1978,162,121-136$

16 M. Krejcik, M. Danek and F. Hartl, J. Electroanal. Chem., 1991, 317, 179-187.

17 F. Hartl, D. J. Stufkens and A. Vlček, Inorg. Chem., 1992, 31, 16871695 .
18 S. J. Sherlock, D. C. Boyd, B. Moasser and W. L. Gladfelter, Inorg. Chem., 1991, 30, 3626-3632.

19 J. Maurer, B. Sarkar, S. Zalis and R. F. Winter, J. Solid State Electrochem., 2005, 9, 738-749.

$20 \mathrm{H}$. Mishra and R. Mukherjee, J. Organomet. Chem., 2007, 692, 32483260 .

21 A. P. Shaw, B. L. Ryland, J. R. Norton, D. Buccella and A. Moscatelli, Inorg Chem, 2007, 46, 5805-5812.

22 F. Paul, B. G. Ellis, M. I. Bruce, L. Toupet, T. Roisnel, K. Costuas, J.-F Halet and C. Lapinte, Organometallics, 2006, 25, 649-665.

23 D. Lin-Vien, N. B. Colthup, W. G. Fateley and J. G. Grasselli, The Handbook of Infrared and Raman Characteristic Frequencies of Organic Molecules, Academic Press, San Diego, 1991.

24 M. A. Esteruelas and H. Werner, J. Organomet. Chem., 1986, 303, 221-231.

25 M. A. Bennett and A. K. Smith, J. Chem. Soc., Dalton Trans., 1974, $233-241$.

26 A. P. Melissaris and M. H. Litt, J. Org. Chem, 1992, 57, 6998-6999.

27 M. J. Frisch, G. W. Trucks, H. B. Schlegel, G. E. Scuseria, M. A Robb, J. R. Cheeseman, J. J. A. Montgomery, T. Vreven, K. N. Kudin, J. C. Burant, J. M. Millam, S. S. Iyengar, J. Tomasi, V. Barone, B. Mennucci, M. Cossi, G. Scalmani, N. Rega, G. A. Petersson, H. Nakatsuji, M. Hada, M. Ehara, K. Toyota, R. Fukuda, J. Hasegawa, M. Ishida, T. Nakajima, Y. Honda, O. Kitao, H. Nakai, M. Klene, X Li, J. E. Knox, H. P. Hratchian, J. B. Cross, C. Adamo, J. Jaramillo, R. Gomperts, R. E. Stratmann, O. Yazyev, A. J. Austin, R. Cammi, C. Pomelli, J. W. Ochterski, P. Y. Ayala, K. Morokuma, G. A. Voth, P. Salvador, J. J. Dannenberg, V. G. Zakrzewski, S. Dapprich, A. D Daniels, M. C. Strain, O. Farkas, D. K. Malick, A. D. Rabuck, K. Raghavachari, J. B. Foresman, J. V. Ortiz, Q. Cui, A. G. Baboul, S. Clifford, J. Cioslowski, B. B. Stefanov, G. Liu, A. Liashenko, P. Piskorz I. Komaromi, R. L. Martin, D. J. Fox, T. Keith, M. A. Al-Laham, C. Y. Peng, A. Nanayakkara, M. Challacombe, P. M. W. Gill, B. Johnson, W. Chen, M. W. Wong, C. Gonzalez and J. A. Pople, Gaussian Inc. Pittsburgh, PA, Editon edn, 2003.

28 G. te Velde, F. M. Bickelhaupt, S. J. A. van Gisbergen, C. Fonseca Guerra, E. J. Baerends, J. G. Snijders and T. Ziegler, J. Comput. Chem. 2001, 22, 931-967.

29 SCM, Vrije Universiteit, Amsterdam, http://www.scm.com, Amsterdam, The Netherlands, Editon edn, 2005.

30 D. Andrae, U. Haeussermann, M. Dolg, H. Stoll and H. Preuss, Theor Chim. Acta, 1990, 77, 123

31 P. H. Hariharan and J. A. Pople, Theor. Chim. Acta, 1973, 28, 213 222.

32 J. P. Perdew, K. Burke and M. Enzerhof, Phys. Rev. Lett., 1996, 77, 3865-3868

33 M. Cossi, N. Rega, G. Scalmani and V. Barone, J. Comput. Chem., 2003, 24, 669-681.

34 A. D. Becke, Phys. Rev. A: At., Mol., Opt. Phys., 1988, 38, 3098-3100.

35 J. P. Perdew, Phys. Rev. B: Condens. Matter, 1986, 33, 8822-8824.

36 E. van Lenthe, A. E. Ehlers and E. J. Baerends, J. Chem. Phys, 1999 , $110,8943-8953$.

37 E. van Lenthe, A. Van Der Avoird and P. E. S. Wormer, J. Chem. Phys, $1998,108,4783-4796$

38 E. van Lenthe, A. Van Der Avoird and P. E. S. Wormer, J. Chem. Phys, 1997, 107, 2488-2498.

39 R. S. Nicholson, Anal. Chem., 1966, 1406 